Prepared in cooperation with the Idaho Department of Environmental Quality

\title{
Estimating Low-Flow Frequency Statistics for Unregulated Streams in Idaho
}

Scientific Investigations Report 2006-5035 


\section{Estimating Low-Flow Frequency Statistics for Unregulated Streams in Idaho}

By Jon E. Hortness

Prepared in cooperation with the

Idhao Department of Environmental Quality

Scientific Investigations Report 2006-5035

U.S. Department of the Interior

U.S. Geological Survey 


\title{
U.S. Department of the Interior \\ Gale A. Norton, Secretary
}

\section{U.S. Geological Survey \\ P. Patrick Leahy, Acting Director}

\section{U.S. Geological Survey, Reston, Virginia: 2006}

\author{
For sale by U.S. Geological Survey, Information Services \\ Box 25286, Denver Federal Center \\ Denver, CO 80225 \\ For more information about the USGS and its products: \\ Telephone: 1-888-ASK-USGS \\ World Wide Web: http://www.usgs.gov/
}

\footnotetext{
Any use of trade, product, or firm names in this publication is for descriptive purposes only and does not imply endorsement by the U.S. Government.

Although this report is in the public domain, permission must be secured from the individual copyright owners to reproduce any copyrighted materials contained within this report.

Suggested citation:

Hortness, J.E., 2006, Estimating low-flow frequency statistics for unregulated streams in Idaho: U.S. Geological Survey Scientific Investigations Report 2006-5035, 31 p.
} 


\section{Contents}

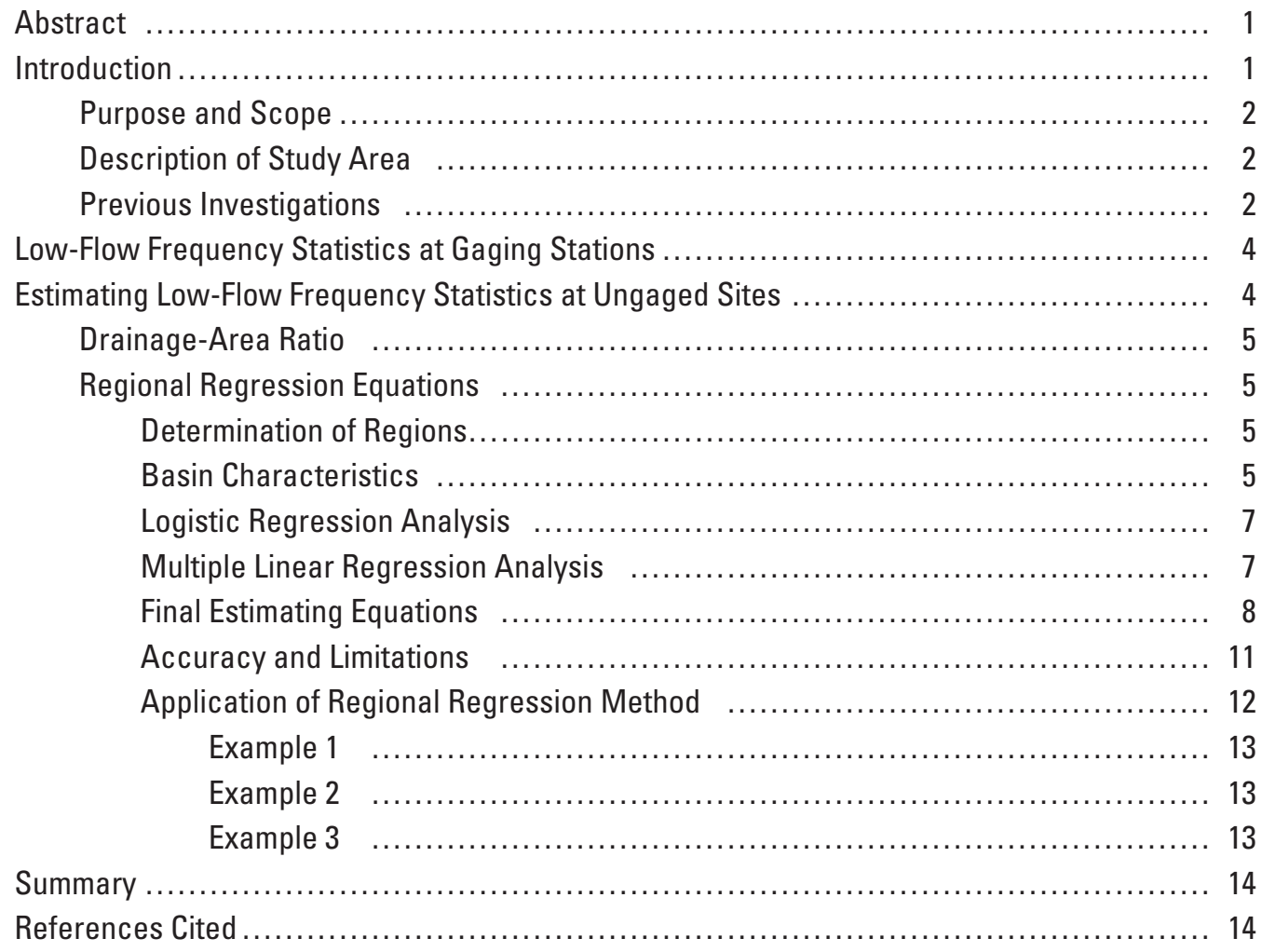




\section{Figures}

Figure 1. Map showing location of the study area, streamflow-gaging stations, and eight regions used to estimate low-flow frequency statistics for unregulated streams in Idaho

Figure 2. Graph showing joint distribution of two example basin characteristics, mean basin elevation and mean annual precipitation

\section{Tables}

Table 1. Sources for data used to obtain basin characteristics used to estimate low-flow frequency statistics for unregulated streams in Idaho

Table 2. Description of basin characteristics used in the final equations for estimating low-flow frequency statistics for unregulated streams in Idaho.....

Table 3. Logistic regression equations used to estimate the probability of zero flow for unregulated streams in regions 4, 6, and 7 in Idaho....

Table 4. Regression equations for estimating low-flow frequency statistics for unregulated streams in regions 1-8 in Idaho

Table 5. Range of values of basin characteristics used to estimate low-flow frequency statistics for unregulated streams in regions 1-8 in Idaho

Table 6. Selected information for gaging stations used to estimate low-flow frequency statistics for unregulated streams in regions 1-8 in Idaho

Table 7. Low-flow frequency statistics for streamflow-gaging stations used in low-flow regression analyses for unregulated streams in regions 1-8 in Idaho

Table 8. Basin characteristics considered during the low-flow regressin analyses for unregulated streams in Idaho

Table 9. Basin characteristic values used to develop the final probability and estimating equations for low-flow frequency statistics for unregulated streams in regions 1-8 in Idaho

Table 10. Total years with the N-day low flow equal to zero and total years of record for streamflow-gaging stations used in logistic regression analyses for unregulated streams in regions 1-8 in Idaho 


\section{Conversion Factors, Datums, Definitions, and Abbreviations and Acronyms}

Conversion Factors

\begin{tabular}{lcl}
\hline Multiply & By & To obtain \\
\hline cubic foot per second $\left(\mathrm{ft}^{3} / \mathrm{s}\right)$ & 0.02832 & cubic meter per second \\
foot (ft) & 0.3048 & meter \\
inch (in.) & 2.54 & centimeter \\
inch per year (in/yr) & 25.4 & millimeter per year \\
mile (mi) & 1.609 & kilometer \\
square mile & 2.590 & square kilometer \\
\hline
\end{tabular}

\section{Datums}

Vertical coordinate information is referenced to the North American Vertical Datum of 1988 (NAVD 88).

Horizontal coordinate information is referenced to the North American Datum of 1983 (NAD 83).

Altitude, as used in this report, refers to distance above the vertical datum.

\section{Definitions}

Water year: In U.S. Geological Survey reports, a water year is the 12-month period from 0ctober 1 through September 30. The water year is designated by the calendar year in which it ends; thus, the water year ending September 30, 2001, is called the "2001 water year".

Climatic year: In U.S. Geological Survey reports, a climatic year is the 12-month period from April 1 through March 31. The climatic year is designated by the calendar year in which it begins; thus, the climatic year beginning April 1, 2001, is called the" 2001 climatic year."

Abbreviations and Acronyms

\begin{tabular}{ll}
\hline Abbreviations and Acronyms & Meaning \\
\hline GIS & Geographic Information System \\
GLS & Generalized Least Squares \\
IDEQ & Idaho Department of Environmental Quality \\
MSE & mean square error \\
NPDES & National Pollution Discharge Elimination System \\
OLS & Ordinary Least Squares \\
TMDL & Total Maximum Daily Load \\
USGS & U.S. Geological Survey \\
\hline
\end{tabular}


This page left intentionally blank 


\title{
Estimating Low-Flow Frequency Statistics for Unregulated Streams in Idaho
}

\author{
By Jon E. Hortness
}

\section{Abstract}

Low-flow frequency statistics are needed by Federal, State, and local agencies for regulatory activities and wateruse planning and management, as well as by commercial and hydroelectric facilities to determine the availability of water for supply and power generation. Logistic and multiplelinear regression analyses were used to develop zero-flowprobability and low-flow-estimating equations for eight separate geographic regions of Idaho and parts of adjacent States, using physical and climatic characteristics as the explanatory variables. As part of this process, the relevant statistics were updated for all gaging stations in Idaho, and some in adjacent States, that, in general, had 10 or more years of record through water year 2003 and were unaffected by regulation and(or) diversions.

Zero-flow-probability equations were developed for three of the eight geographic regions. These equations can be used to estimate the annual probability that the 1-, 7-, or 30-day low flows will equal zero. Using only data from the gaging stations used in the development process (sample data), these equations produced results with percent-correct values ranging from 74 to 100 percent. Any variability in the zero-flow characteristics within each region that was not represented by the data used to develop the equations may affect the predictive accuracy of the final equations.

Estimating equations were developed that can be used for estimating the $1 Q_{10}, 7 Q_{2}, 7 Q_{10}$, and $30 Q_{5}$ low-flow frequency statistics at ungaged, unregulated sites on streams in Idaho. The standard errors of prediction for these equations exhibited a minimum range of +26.9 to -21.2 percent and a maximum range of +311 to -75.7 percent. The $7 Q_{2}$ estimating equations generally exhibited the lowest standard errors and the $1 Q_{10}$ equations generally exhibited the largest standard errors. The equations may not yield reliable results for sites with basincharacteristic values that are outside of the range of values used to develop the equations. The equations also are not applicable for sites on regulated streams or on streams that are affected by significant gains and(or) losses resulting from factors including spring flow, channel seepage, diversions, and irrigation returns.

\section{Introduction}

Frequency statistics, such as the 7-day, 10-year low flow [7 $Q_{10}$; annual minimum mean discharge for 7 consecutive days, which has a $0.1(1 / 10 ; 10$ percent) probability of not being exceeded in any one year], commonly are used by States when setting effluent limits and allowable pollutant loads to meet water-quality standards. These same low-flow frequency statistics also indicate the probable availability of water in streams during times when conflicts between water supply and demand are most prevalent. Because of this, low-flow statistics are needed by Federal, State, and local agencies for regulatory activities and water-use planning and management. Lowflow statistics also are used by commercial and hydroelectric facilities to determine the availability of water for supply and power generation.

In Idaho, more than 800 river reaches have been designated as impaired [exceeding water-quality and(or) biological criteria]. These reaches have or will have their load of pollutants analyzed and maximum loading rates set by Total Maximum Daily Load (TMDL) assessments. To determine the load of a constituent in a stream, streamflowquantity information is needed. This information is especially important for low-flow periods when agencies need to determine the maximum effluent limits for National Pollution Discharge Elimination System (NPDES) discharge permits.

The U.S. Geological Survey (USGS) operates a network of streamflow-gaging stations in Idaho that provides streamflow data for a variety of purposes, and low-flow statistics can be calculated from the streamflow data collected at these locations. However, it is not feasible to operate gaging stations at all locations where low-flow statistics are needed. Because of this, methods are needed that can be used to estimate low-flow statistics at locations where no streamflow information exists. This is most often accomplished using regionalization techniques and regression analyses that relate low-flow statistics to selected physical and climatic characteristics of drainage basins. 
The last Statewide evaluation of low-flow characteristics by the USGS was published in 1996 and included flow data through 1990 (Kjelstrom and others, 1996). Although this report included low-flow statistics over a wide range of flow durations and recurrence intervals, it only included low-flow statistics at gaged sites with 10 or more years of continuous record. Because methods are needed to estimate low-flow statistics at ungaged sites throughout Idaho, the USGS, in cooperation with the Idaho Department of Environmental Quality (IDEQ), began a study to develop methods for estimating the $1 Q_{10}, 7 Q_{2}, 7 Q_{10}$, and $30 Q_{5}$ low-flow frequency statistics at ungaged sites. In the past, estimating low-flow statistics at ungaged sites has met with only limited success because of difficulties in adequately describing the effects of geology and other factors that typically affect low flows (Riggs, 1972). The use of GIS (Geographic Information System) to obtain a larger number of basin characteristics, especially geologic characteristics, and the improved accuracy of source data may significantly improve the success of this method.

\section{Purpose and Scope}

This report presents techniques used to develop regional regression equations that can be used to estimate various low-flow statistics for ungaged sites on unregulated streams in Idaho. Multiple linear regression analyses were used to develop equations for estimating the $1 Q_{10}, 7 Q_{2}, 7 Q_{10}$, and $30 Q_{5}$ low-flow frequency statistics at ungaged, unregulated sites on streams in Idaho, and logistic regression analyses were used to develop equations for estimating the zero-flow probability for 1-, 7-, and 30-day low flows. The report also describes the associated reliability and limitations of the regression equations. Regression statistics, such as the standard error of estimate, were calculated to help assess the reliability and accuracy of each equation.

Relevant low-flow frequency statistics $\left(1 Q_{10}, 7 Q_{2}, 7 Q_{10}\right.$, and $30 Q_{5}$ ) were updated for the gaging stations in Idaho and adjacent States used in the equation development process. These gaging stations included all those in Idaho, and some in adjacent States, with generally 10 or more years of record on streams unaffected by regulation and(or) diversions. Relevant low-flow statistics updated through water year 2003 for these gaging stations also are presented in this report.

\section{Description of Study Area}

The study area (fig. 1) includes the entire State of Idaho and areas in the adjacent States of Washington, Oregon, Nevada, Utah, Wyoming, and Montana where particular drainage basins cross over State boundaries. The northern and central parts of the area are composed mainly of rugged, mountainous terrain; broad plains and mildly sloping valleys and hills predominate in the south. Geologic features across the study area consist of sedimentary, igneous, and metamorphic rocks ranging in age from Precambrian to Holocene (Bond, 1978). The granitic Idaho batholith is the major structural feature in the central part of the study area, and basalt covers much of the southern and western parts (Ross and Savage, 1967).

Most precipitation in the study area results from storms moving inland from the Pacific Ocean. The amount of precipitation varies widely throughout the area and is greatly affected by topography. Precipitation ranges from less than $10 \mathrm{in} / \mathrm{yr}$ on the Snake River Plain in south-central Idaho to 60 to $70 \mathrm{in} / \mathrm{yr}$ in the central mountains of Idaho (Molnau, 1995). The most significant amounts of precipitation are a direct result of orographic effects and occur primarily in the winter months. Spring and summer thunderstorms in the southern part of the study area sometimes produce large amounts of localized precipitation. Resulting streamflow varies geographically and seasonally and can be affected by land use and vegetation. During much of the year, typically August through March, streamflow in most unregulated streams in the study area is minimal base flow; during April, May, June, and July, streamflow is significantly greater, primarily as a result of snowmelt. Annual minimum streamflows typically occur during October through January. Occasionally during the winter months, large frontal systems carrying warmer air release moisture as rain on the snowpack and frozen ground, which results in rapid snowmelt and high runoff rates, particularly at altitudes less than $6,000 \mathrm{ft}$ above sea level (National Oceanic and Atmospheric Administration, 1971).

\section{Previous Investigations}

Various low-flow statistics for selected gaging stations in Idaho with 10 or more years of record through 1990 were determined by Kjelstrom and others (1996). The statistics included the annual minimum mean discharges for periods of $1,3,5,7,14,30,60,90,120$, and 183 consecutive days for recurrence intervals of 2, 5, 10, 20, 50, and 100 years. Kjelstrom and others (1995) also documented annual minimum discharges for selected gaging stations in Idaho with 5 to 9 years of record through 1990 .

Although no studies have been completed that document methods for estimating low-flow statistics at ungaged sites in Idaho, several studies resulted in methods for estimating monthly-exceedance, annual-mean, and peak-flow statistics at ungaged sites. Most recently, regional regression techniques were used to develop equations that can be used to estimate various streamflow statistics at ungaged sites. These techniques resulted in equations for estimating the following statistics: monthly-exceedance and annual-mean discharges (Hortness and Berenbrock, 2001); peak-flow discharges (Berenbrock, 2002); and bankfull-flow discharges (Hortness and Berenbrock, 2003). 




Base from U.S. Geological Survey digital data, 1:2,000,000, 1999; Regions based on Hydrologic Unit Boundaries, 1:2,000,000, 1999;

Transverse Mercator projection. Factor at central meridian: 0.99960 . Longitude of central meridian: $-114^{\circ} 00^{\prime}$. Latitude of origin: $42^{\circ} 00^{\circ}$

False easting (meters): 500,000.0 False northing (meters): 100,000.0

Figure 1. Location of the study area, streamflow-gaging stations, and eight regions used to estimate low-flow frequency statistics for unregulated streams in Idaho. 
Quillian and Harenberg (1982) and Horn (1988) developed methods for estimating mean annual discharges in streams across Idaho. Kjelstrom (1998) developed a method for estimating the 20-, 50-, and 80-percent monthlyexceedance discharge values for the Salmon and Clearwater River Basins in central Idaho using the mean monthly discharge and a multiplication factor. This method pertains only to the approximately 1,050 subbasins identified by Lipscomb (1998), who estimated the mean monthly discharges for each subbasin by apportioning mean annual discharges into monthly increments on the basis of records from gaging stations selected as being characteristic of the subbasin. Lipscomb estimated the mean annual discharges by using the regional regression equations developed by Quillian and Harenberg (1982).

Thomas and others (1973), Kjelstrom and Moffatt (1981), and Quillian and Harenberg (1982) developed regional regression equations for estimating peak flows at ungaged sites in Idaho. Portions of Idaho also were included in regional peak-flow studies by Hedman and Osterkamp (1982) and Thomas and others (1994). Regression equations specific to bankfull flows were developed for the Salmon River Basin by Emmett (1975) and for the entire State by Harenberg (1980).

\section{Low-Flow Frequency Statistics at Gaging Stations}

Low-flow frequency statistics are determined using the annual minimum mean flows for any given number of days (N-day low flows) during an annual period. The mean flow for each N-day period throughout the annual period is computed and the minimum value is used for that period. The series of annual minimum $\mathrm{N}$-day values are then fit to a log-Pearson Type III distribution to determine the recurrence intervals (Riggs, 1972). The annual period referred to as a climatic year (April 1 through March 31) is often used in low-flow analyses because the annual low-flow period in most parts of the country occurs during the late summer and autumn months. Use of the climatic year allows for inclusion of the entire low-flow period in the same year, whereas use of the traditional water year (October 1 through September 30) may artificially separate the low-flow period into two different years.

Updated relevant low-flow frequency statistics $\left(1 Q_{10}\right.$, $7 Q_{2}, 7 Q_{10}$, and $30 Q_{5}$ ) were computed for 234 gaging stations located throughout Idaho and portions of the adjacent States (fig. 1). This included all of those gaging stations located in Idaho and those in adjacent States within about an 80-mi buffer surrounding Idaho that, in general, had 10 or more years of record through water year 2003, exhibited little or no signs of trends, and were unaffected by regulations and/or diversions. A small number of gaging stations with fewer than 10 years of record were included in the analyses after the data were analyzed and found to contain a broad enough range of streamflow conditions that they would not bias the statistical results. Selected information for each gaging station included in the final dataset are presented in table 6 (at back of report) and the relevant low-flow frequency statistics for each gaging station are presented in table 7 (at back of report).

Streamflow data were analyzed for trends using Kendall's tau hypothesis test. Trends in the data could introduce an element of error into the frequency analyses, since a major assumption is that annual low flows are independent and stationary over time. The Kendall's tau test measures the monotonic relationship between two data sets, in this case, streamflow and time (Helsel and Hirsch, 1992). A relatively stringent $P$-value threshold of 2 percent $(\alpha=0.02)$ was used in this study. Data from gaging stations that exhibited trends based on this criteria were analyzed further and compared to data from nearby gaging stations to determine inclusion or exclusion from the dataset.

Streamflow data were screened to prevent data affected by regulations and/or diversions from biasing the dataset. Decisions to include or exclude data from a specific gaging station were made using hydrologic judgment based on all available information regarding the occurrence, timing, and magnitude of regulations and diversions upstream of the gaging stations. No specific criteria were used. In general, all gaging stations with data affected by upstream regulations were removed from the dataset, as well as those with data affected by upstream diversions during typical low-flow periods. The information available was not always complete and the accuracy was questionable in some cases, especially with regard to magnitudes of upstream diversions. Therefore, it is possible that data affected by regulations or diversions could have been included in the final datasets. However, the overall effects on the data are believed to be minimal.

\section{Estimating Low-Flow Frequency Statistics at Ungaged Sites}

Because gaging stations cannot be located at all sites where streamflow information is needed, other methods are used to estimate streamflow statistics for these sites. The two most commonly used methods for estimating streamflow statistics at ungaged sites are the drainage-area ratio method and regression equations (Ries and Friesz, 2000). The drainage-area ratio method can be used when the ungaged site is located near a gaging station on the same stream. Regression equations can be used to estimate streamflow statistics at most ungaged sites. 


\section{Drainage-Area Ratio}

A major assumption of the drainage-area ratio method is that the streamflow at the ungaged site is the same per unit area as the streamflow at a nearby gaging station located on the same stream (index site). The method involves determining the drainage areas for both the ungaged site and the index site. The streamflow statistics are computed for the index site and then are divided by the drainage area to determine the streamflow per unit area for each statistic. The values for streamflow per unit area are then multiplied by the drainage area for the ungaged site to estimate the statistics for that site. The accuracy of this method depends on the proximity of the two sites and the similarities in drainage area and other physical and climatic (basin) characteristics of their drainage basins. The equation that represents this method is as follows:

$$
Q_{u}=\left(\frac{D A_{u}}{D A_{g}}\right) Q_{g},
$$

where

$Q_{u}$ is the streamflow statistic for the ungaged site,

$D A_{u}$ is the drainage area for the ungaged site,

$D A_{g}$ is the drainage area for the gaged site, and

$Q_{g}$ is the streamflow statistic for the gaged site.

It is fairly common practice to use this method when the sites are located on the same stream and the ratio between the drainage areas of the index site and the ungaged site is between 0.5 and 1.5. On the basis of specific analyses in certain areas, some researchers have found that this range should be either reduced or expanded. Koltun and Schwartz (1986) recommended a range of 0.85 to 1.15 times the area of the index site for estimates of low-flow statistics in Ohio, and Ries and Friesz (2000) determined that a range of 0.3 to 1.5 was applicable for low-flow statistics in Massachusetts. Parrett and Johnson (2004) recommended the standard ratio of 0.5 to 1.5 for flood frequency analyses in Montana, as did Berenbrock (2002) and Kjelstrom (1998) for flood-frequency analyses in Idaho.

\section{Regional Regression Equations}

The regression analyses were completed for eight separate geographic regions of the State, as was done in the recent peak-flow and monthly exceedance studies (Hortness and Berenbrock, 2001 and 2003; Berenbrock, 2002). Basin and climatic variables (basin characteristics) for the gaging stations used in this study were obtained from previous studies or determined using GIS algorithms equivalent to those used in previous studies. Two types of regression analyses, logistic and multiple linear, were used. Logistic regression analysis was used for regions that included gaging stations at which any of the relevant $\mathrm{N}$-day low flows equaled zero. Data from those stations were used to develop an equation for use in determining the probability of the annual minimum $\mathrm{N}$-day flow being zero for an ungaged site. Multiple linear regression analyses were used in all regions to develop equations for estimating low-flow frequency statistics.

\section{Determination of Regions}

The regional boundaries used in this study are the same ones that were defined by Hortness and Berenbrock (2001): eight study regions and one undefined region that was not included in the analysis (fig. 1). The region boundaries were determined on the basis of the following: (1) grouping of gages with similar basin characteristics revealed during cluster analyses (statistical method for grouping data with similar characteristics), (2) location of geographic features, such as large mountain ranges or breaks between mountains and plains, and (3) use of hydrologic judgment based on general knowledge of the area. The undefined region is made up almost entirely of the area commonly referred to as the eastern Snake River Plain. This area includes several dams, major irrigation diversions, springs with extremely large discharges, and flat-land drainages and channel bottoms with very high infiltration rates. This area was not included in the analysis because flows influenced by these conditions cannot be characterized by a regional regression approach. More detailed information on how the regional boundaries were determined can be found in the previous report by Hortness and Berenbrock (2001).

\section{Basin Characteristics}

More than 30 separate basin characteristics were obtained for each of the 234 gaging stations included in this study. The basin characteristics for gaging stations included in previous studies by Hortness and Berenbrock $(2001 ; 2003)$ and Berenbrock (2002) were used in this study. For gaging stations not included in those studies, the basin characteristics were derived using current GIS techniques equivalent to those used in the previous studies. In general, all basin characteristics were obtained using either custom Arc Macro Language (AML) programs written for ArcGIS or current tools (ArcHydro Tools) available in ArcGIS version 9.0 (Environmental Systems Research Institute, Inc., 2005). The sources for the values of all basin characteristics are given in table 1 and a list of all basin characteristics considered during this study are presented in table 8 (at back of report).

Several basin characteristics were removed from consideration after a review of the correlation plots of the data. Generally, if two basin characteristics correlated well with each other, the one that was the least difficult to obtain was kept and the other was removed. Other characteristics were removed because of missing data or difficulty in obtaining the data. Descriptions of the basin characteristics used in the final equations and the methods of determination are provided in table 2, and basin-characteristic values for each gaging station are listed in table 9 (at back of report). 
Table 1. Sources for data used to obtain basin characteristics used to estimate low-flow frequency statistics for unregulated streams in Idaho.

\begin{tabular}{|c|c|}
\hline Dataset & Source \\
\hline National Elevation Dataset (NED) & $\begin{array}{l}\text { Several basin characteristics were calculated using 30-meter-resolution digital-elevation data derived } \\
\text { from the 1-arc-second National Elevation Dataset (NED) (URL: http://ned.usgs.gov/). }\end{array}$ \\
\hline $\begin{array}{l}\text { Elevation Derivatives for National } \\
\text { Applications (EDNA) }\end{array}$ & $\begin{array}{l}\text { Hydrologic derivatives of NED data were developed using procedures similar to those of EDNA } \\
\text { Stage } 1 \text { processing, using a custom projection for Idaho (URL: } \underline{\text { htp://edna.usgs.gov/Edna/ }} \\
\text { methodology.asp). }\end{array}$ \\
\hline National Land Cover Dataset (NLCD) & $\begin{array}{l}\text { Vogelmann, J.E., Sohl, T.L., Campbell, P.V., and Shaw, D.M., 1998, Regional land-cover } \\
\text { characterization using Landsat Thematic Mapper data and ancillary data sources: Environmental } \\
\text { Monitoring and Assessment v. 51, p. 415-428 (URL: http://landcover.usgs.gov/natllandcover.asp). }\end{array}$ \\
\hline Major lithology, Pacific Northwest & $\begin{array}{l}\text { U.S. Geological Survey, 1995, Major lithology: Spokane, Washington, U.S. Geological Survey, } \\
\text { polygon data converted to grid-cell resolution } 200 \text { meters (URL: http://www.icbemp.gov/spatial/ } \\
\underline{\text { min). }}\end{array}$ \\
\hline $\begin{array}{l}\text { Mean annual precipitation, Idaho } \\
\text { (used for areas within Idaho) }\end{array}$ & $\begin{array}{l}\text { Molnau, M., 1995, Mean annual precipitation, 1961-1990, Idaho: Moscow, University of Idaho, } \\
\text { Agricultural Engineering Department, State Climate Program, scale 1:1,000,000 (URL: } \underline{\text { ttp:// }} \\
\text { snow.ag.uidaho.edu/Climate/reports.html). }\end{array}$ \\
\hline $\begin{array}{l}\text { Western United States average monthly } \\
\text { or annual precipitation } \\
\text { (PRISM; used for areas outside of } \\
\text { Idaho) }\end{array}$ & $\begin{array}{l}\text { Daly, C., and Taylor, G., 1998, Western United States average monthly or annual precipitation, 1961- } \\
\text { 90, Oregon: Portland, Water and Climate Center of the Natural Resources Conservation Service, } \\
\text { grid-cell resolution } 4 \text { kilometers (URL: http://www.ocs.orst.edu/prism/prism new.html). }\end{array}$ \\
\hline
\end{tabular}

Table 2. Description of basin characteristics used in the final equations for estimating low-flow frequency statistics for unregulated streams in Idaho.

\section{Basin characteristic (identifier)}

Drainage area $(A)$

Mean annual precipitation $(P)$

Developed land $(D V)$

Agricultural land $(A G)$

Basin slope $(B S)$

Water $(W)$

Basin relief $(R)$

Surficial volcanic rocks $(V)$

Slopes greater than 50 percent (S50)

\section{Description}

Drainage area of the basin that contributes surface runoff, in square miles; estimated using Arc/Info Grid with 30-meter-resolution digital-elevation models (DEMs).

Mean annual precipitation over the entire drainage area, in inches; estimated using Arc/Info Grid with a combination of 500-meter resolution (within Idaho) and 4-kilometer resolution (outside of Idaho) precipitation grids covering the 1961-1990 period.

Areas of residential, commercial, industrial, and transportation lands, in percentage of drainage area; estimated from the National Land Cover Dataset (NLCD) 1992 version.

Areas of pasture, row crop, small grain, fallow, and urban/recreational grass lands, in percentage of drainage area; estimated from the National Land Cover Dataset (NLCD) 1992 version.

Average slope of the basin, in percent; estimated using the SLOPE function in Arc/Info Grid with 30-meter-resolution DEMs.

Areas of open water or perennial ice and snow, in percentage of drainage area; estimated from the National Land Cover Dataset (NLCD) 1992 version.

Relief of the basin, in feet; estimated using Arc/Info Grid with 30-meter-resolution digital-elevation models (DEMs).

Areas of surficial volcanic rocks, in percentage of drainage area; estimated from the Pacific Northwest Major Lithology data set.

Area with slopes greater than 50 percent, in percentage of drainage area; estimated using the SLOPE function in Arc/Info Grid with 30-meter-resolution DEMs. 


\section{Logistic Regression Analysis}

Logistic regression analyses were used to develop equations that relate the probability of a specific $\mathrm{N}$-day low flow equaling zero to basin characteristics. The use of logistic regressions for water-resources applications is discussed in more detail by Helsel and Hirsch (1992). Applications specific to low-flow analyses can be found in a paper by Tasker (1989) and a report by Ludwig and Tasker (1993). Hosmer and Lemeshow (2000) provide a complete discussion of logistic regression.

The output variable in a logistic regression equation is dichotomous (binary), meaning that there are two possible outcomes. In this study, the possible outcomes were flow or no flow. Logistic regression is conceptually similar to multiple linear regression because the relation between one dependent variable and several independent variables is evaluated. The differences are reflected in the form of the equation and in the assumptions. Four important concepts regarding logistic regression analyses are as follows: (1) the conditional mean of the regression equation must fall between zero and 1 ;

(2) the distribution of the errors is binomial, not normal;

(3) equation coefficients are estimated using the log likelihood function, not least squares as is done in linear regression; and (4) the general principles that guide the development of linear regression equations are also relevant for logistic regression (Hosmer and Lemeshow, 2000).

The final form of the logistic regression equation results in a probability of success of one of the two possible outcomes. For this study, it was the probability that the specific N-day low flow is equal to zero. The final form of the logistic regression equation can be written as follows:

$$
P_{\text {zero }}=\frac{e^{\left(a+c_{1} V_{1}+c_{2} V_{2}+\ldots+c_{n} V_{n}\right)}}{1+e^{\left(a+c_{1} V_{1}+c_{2} V_{2}+\ldots+c_{n} V_{n}\right)}},
$$

where

$P_{z e r o}$ is the probability of the N-day low flow being equal to zero,

$a$ is the regession model constant,

$e$ is a mathematical constant,

$c_{1}$ to $c_{n}$ are the regression model coefficients, and

$V_{1}$ to $V_{n}$ are the required basin characteristics.

Data from each of the gaging stations listed in table 6 were used in the logistic regression analyses. The Statit Custom QC (Statit Software, 2005) statistical software package was used to perform the logistic regression analyses. The data required to perform the analyses included the total number of years of record, total number of years that each of the specific $\mathrm{N}$-day low flows equaled zero, and basin characteristics for each gaging station in the region being analyzed. In the analyses, the number of years that the specific N-day low-flow equaled zero was the dependent variable, the total number of years of record was the binomial trials variable (number of possible zero-flow years), and the basin characteristics were the independent variables. The total years of N-day zero flows and total years of record for each of the gaging stations are presented in table 10 (at back of report). Only region 2 had no gaging stations with at least 1 year where one of the $\mathrm{N}$-day low flows equaled zero. Basin-characteristic data for the gaging stations were presented previously in table 9 .

Several statistical parameters were used to help with the selection of the final probability equations. The overall likelihood ratio tests whether the model coefficients are significantly different from zero. This ratio follows a chi-squared distribution and computed $p$-values indicate whether model coefficients are significantly different from zero. A $p$-value threshold of 0.05 was used for this analysis. McFadden's $R^{2}$ is a transformation of the log-likelihood ratio intended to be similar to the unadjusted $R^{2}$ in linear regression. However, McFadden's $R^{2}$ tends to be smaller than $R^{2}$ in linear regression. The percentage of correct responses is calculated as the number of observed zero flows that were predicted by the model as zero flows, plus the number of non-zero flows predicted by the model as non-zero flows, divided by the total number of gaging stations used in the analysis. The odds ratio is a measure of the relative influence of an independent variable on the model.

\section{Multiple Linear Regression Analysis}

The use of multiple linear regression equations is the most common method used for estimating streamflow statistics at ungaged sites. In multiple linear regression analyses, streamflow statistics from several long-term gaging stations are statistically related to various basin characteristics for each of the gaging stations. The resulting equation can then be used with the relevant basin characteristics to estimate streamflow statistics at ungaged sites where no streamflow data are available.

The typical form of equations generated from multiple linear regression analyses is

$$
Y_{i}=b_{0}+b_{1} X_{1}+b_{2} X_{2}+\ldots+b_{n} X_{n}+\varepsilon_{i},
$$

where

$Y_{i}$ is the estimate of the dependent variable for site $i$, $b_{0}$ to $b_{n}$ are the $n+1$ regression model coefficients,

$X_{i}$ to $X_{n}$ are the $n$ independent variables, and

$\varepsilon_{i}$ is the residual error (difference between the observed and estimated values of the dependent variable) for site $i$.

Four assumptions are associated with the regression analyses: (1) the mean of $\varepsilon_{i}$ is zero, (2) the variance of $\varepsilon_{i}$ is constant and independent of the values of $X_{n}$, (3) the values for $\varepsilon_{i}$ are normally distributed, and (4) the values for $\varepsilon_{i}$ are independent of each other (Haan, 1977). 
Streamflow statistics and basin characteristics generally are log-normally distributed. As a result, a log transformation of the variables is necessary to satisfy assumption 1 above. The use of log-transformed values results in an equation of the following linear form:

$$
\log Y_{i}=b_{0}+b_{1} \log X_{1}+b_{2} \log X_{2}+\ldots+b_{n} \log X_{n}+\varepsilon_{i} \text {. (4) }
$$

The coefficients for this equation are derived from the multiple linear regression analyses and then the equation is transformed back to original units. The retransformed equation takes on the following form:

$$
Y_{i}=10^{b_{0}} X_{1}^{b_{1}} X_{2}^{b_{2}} \ldots X_{n}^{b_{n}} 10^{\varepsilon_{i}} .
$$

In hydrologic terms, assuming that $\varepsilon_{i}$ is zero as stated in the assumptions above, the equation can be written as:

$$
Q_{i}=a V_{1}^{c_{1}} V_{2}^{c_{2}} \ldots V_{n}^{c_{n}},
$$

where

$Q_{1}$ is the low-flow statistic,

$a$ is the model constant transformed back to original units,

$V_{1}$ to $V_{n}$ are the required basin characteristics, and

$c_{1}$ to $c_{n}$ are the regression model coefficients.

Because streamflow data are essentially correlated spatially and in time, assumption 4 is not strictly satisfied when the most commonly used form of regression analysis, Ordinary Least Squares (OLS) is used. As a result, Generalized Least Squares (GLS) regression techniques were developed for use in regression analysis of peak- and low-flow frequency statistics. GLS techniques are the most appropriate for dealing with hydrologic regressions because the algorithms allow for the weighting of station data to compensate for spatial correlation and differences in record length (Tasker and Stedinger, 1989). For this study, OLS techniques were used to narrow down the list of possible explanatory variables (basin characteristics) and then GLS techniques were used to determine the final estimating equations. The Statit Custom QC (Statit Software, 2005) statistical software package was used to perform the initial regressions using OLS techniques and the USGS software package GLSNET (U.S. Geological Survey, 1998) was used to finalize the equations using GLS techniques.

Because the regression technique for low-flow statistics requires a $\log$ transformation, zero values cannot be used in the multiple linear regression analyses. All gaging stations listed in table 6 were used in the analyses except those with specific low-flow statistics equal to zero (see table 7). Depending on the values of the various low-flow statistics for a specific gaging station, it would be possible to include the gaging station in the analysis for one statistic but exclude it from the analysis for another. The basin characteristic values used in the analyses were presented previously in table 8. To ensure that zero values, which cannot be transformed, would not result for any gaging station, 1 percent was added to the values of the following basin characteristics prior to the log transformation: developed land $(D V)$, agricultural land $(A G)$, water $(W)$, volcanic rock $(V)$, and slopes greater than 50 percent $(S 50)$.

In addition, basin relief $(R)$ was divided by 1,000 prior to transformation to allow for more convenient coefficients in the final equations.

The final equations were chosen primarily, but not exclusively, on the basis of the following statistical parameters: (1) mean square error (MSE), the model error variance of the estimates for the stations included in the analysis; (2) $R^{2}$ adj, the percentage of the variation in the dependent variable explained by the independent variables, adjusted for the number of stations and the number of independent variables used in the regression analysis; and (3) the PRESS statistic, an estimate of the prediction error sum of squares. In the end, simpler equations were chosen over more complex equations if the statistical parameters were similar.

\section{Final Estimating Equations}

Logistic regression analyses were performed for each of the regions with at least one gaging station with $\mathrm{N}$-day low-flow data equal to zero (all the regions except region 2). The analyses in three of those regions-4, 6, and 7-resulted in equations that were statistically significant for estimating the annual probability of zero flows for 1-, 7-, and 30-day periods. Likely reasons why statistically significant equations could not be developed for regions $1,3,5$, and 8 are that there were a relatively small number of gaging stations with $\mathrm{N}$-day low-flow values equal to zero or there were a small number of zero values per gaging station.

The logistic regression equations developed for regions 4,6 , and 7 are presented in table 3 and should be used to determine the probability of the specific annual minimum $\mathrm{N}$-day flows equaling zero for ungaged sites in those regions before low-flow frequency statistics are estimated. Values for some of the previously defined statistical parameters used to evaluate the quality of the equations are included in table 3. If the resulting probability is greater than the non-exceedance probability for the statistic of interest, then the expected value for that statistic would be zero and the low-flow frequency equations should not be used. If the resulting probability is less than the non-exceedance probability for the statistic of interest, then the low-flow frequency equations should be used to estimate the value of the statistic. For example, if the probability of a specific 7-day low flow equaling zero was 0.35 from the equation, the expected value for the $7 Q_{10}$ statistic would be zero $(0.35>0.10$ or $1 / 10)$, and the expected value for the $7 Q_{2}$ statistic would be greater than zero $(0.35<0.50$ or $1 / 2)$ and should be estimated using the low-flow frequency equation. 
Table 3. Logistic regression equations used to estimate the probability of zero flow for unregulated streams in regions 4, 6, and 7 in Idaho.

[Locations of regions are shown in figure 1 . Zero flow annual probability equation: $P_{\mathrm{n} \text {-day }}$, annual probability of zero flow for $n$ days; $A$, drainage area in square miles; $P$, mean annual precipitation, in inches; $D V$, developed land in percentage of drainage area; $A G$, agricultural land in percentage of drainage area; $B S$, basin slope in percent. OLR: Overall likelihood ratio. OLR-p: chi-square $p$-value for the overall likelihood ratio. Percentage correctly estimated: Based only on the sample data used to develop the equation]

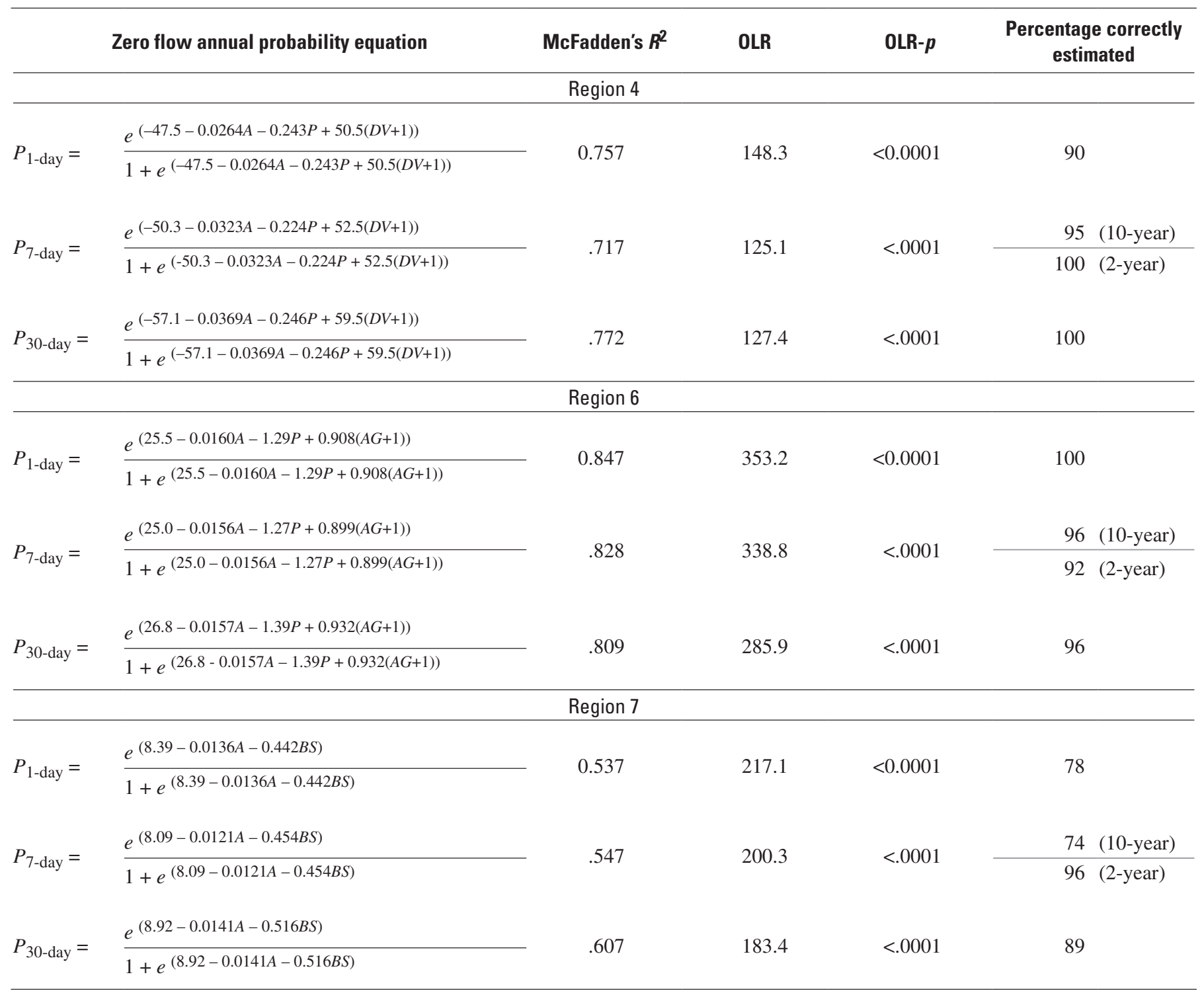

Although equations were not able to be developed for regions $1,3,5$, and 8 , the data show that it is possible, though not very common, to have occurrences of zero flow at certain locations within these regions. Thus, low-flow estimates approaching zero for ungaged sites (determined from the regression equations) may need additional analyses to determine if zero flows also are likely. Analyses could include comparisons of basin characteristics to gaging stations with known zero-flow occurrences in the same region (table 10) or field observations during expected low-flow periods.

Multiple linear regression analyses resulted in the development of four equations to estimate the low-flow frequency statistics $1 Q_{10}, 7 Q_{2}, 7 Q_{10}$, and $30 Q_{5}$ for unregulated streams in each of the eight regions in the State. The final equations are presented in table 4, along with the associated standard error of the model and the standard error of prediction for each equation. The standard error of the model measures how well the regression model fits the data used to develop it. The standard error of prediction includes the model error as well as an estimate of the sample error and is a better indicator of the model's overall predictive ability (Pope and others, 2001). The values presented in $\log _{10}$ format represent the errors of the log-transformed equations. The percentage values represent the range of errors for the final untransformed equations. These values were determined using error transformation equations presented in Riggs (1968). 
Table 4. Regression equations for estimating low-flow frequency statistics for unregulated streams in regions 1-8 in Idaho.

[Locations of regions are shown in figure 1. Low-flow frequency equation: $A$, drainage area, in square miles; $B S$, basin slope, in percent; $P$, mean annual precipitation, in inches; $R$, basin relief, in feet; $S 50$, slopes greater than 50 percent in percentage of drainage area; $V$, surficial volcanic rocks, in percentage of drainage area; $W$, water, in percentage of drainage area]

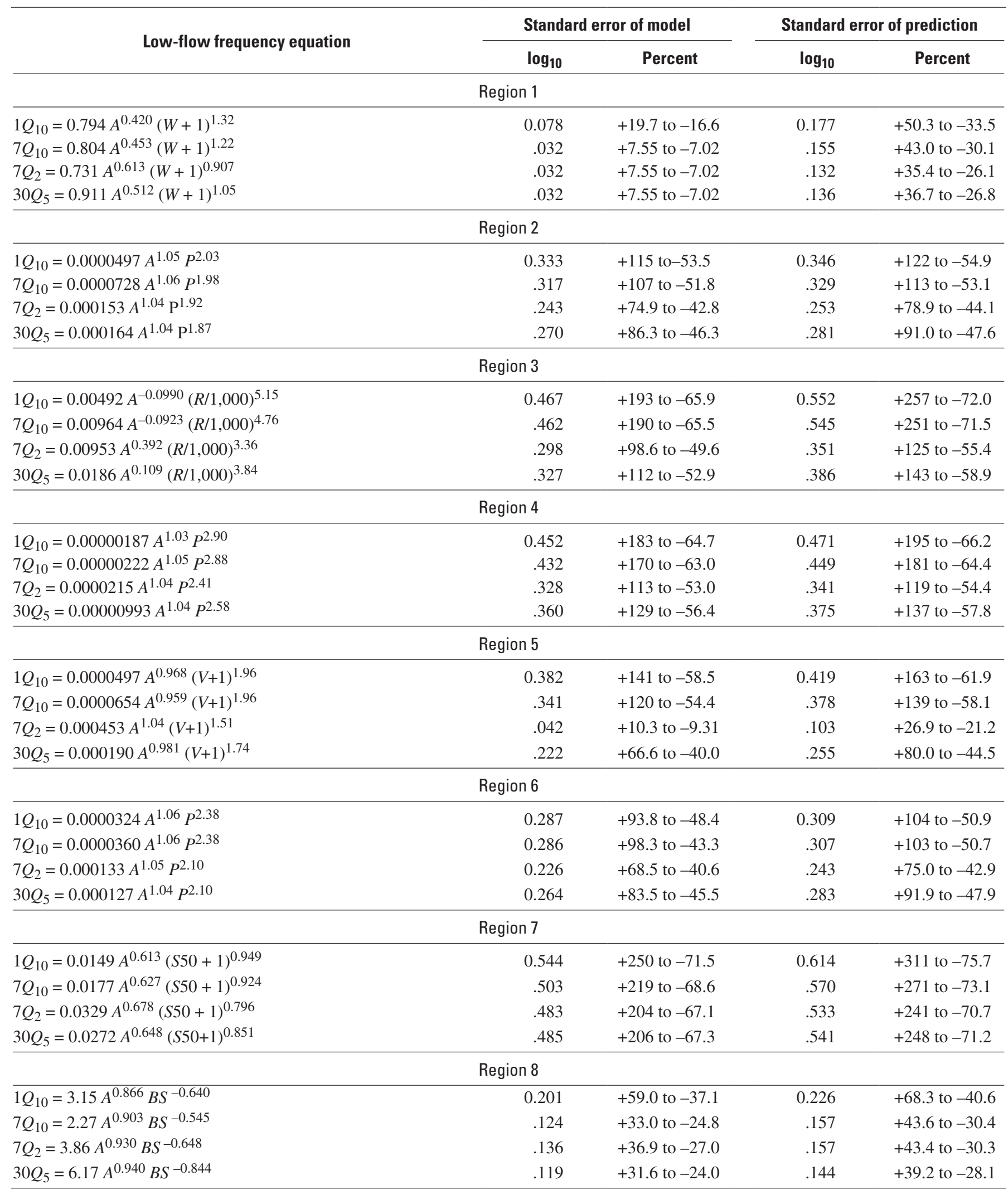




\section{Accuracy and Limitations}

The percentage of correct values for the zero-flow probability equations ranged from 74 to 100 percent (table 3 ). The values for regions 4 and 6 were all 90 percent or higher. The values for region 7 ranged from 74 to 96 percent. These values provide an indication of the accuracy of the equations based only on the data used to develop the equations. It is assumed that the data used in each region provide a good representation of the zero-flow characteristics of streams in the region. However, any variability in the zero-flow characteristics within each region that was not represented in the development of the equations may have an effect on the final predictive accuracy of the equations.

The model and prediction standard errors for the final estimating equations range significantly across the eight regions (table 4). Equations for regions 1 and 8 had relatively low standard errors, whereas those for regions 3 and 7 were quite large. The large errors associated with the region 3 equations may be the result of the low number of gaging stations (eight) available for the analysis. The large errors associated with the region 7 equations likely indicate that the available basin characteristics do not adequately represent the factors that affect low flows in this area. The natural variability of streamflow may also be an important factor. Prediction of streamflow statistics that have a high degree of variability will always have more uncertainty than prediction of statistics that are more stable. Hortness and Berenbrock (2001) noted that the natural variability of streamflow in regions 6 and 7 is generally greater than the natural variability in the other regions. It is also important to note that even a large percentage error associated with low-flow values does not necessarily result in a large-magnitude error range around the value. For example, a low-flow value of $5.0 \mathrm{ft}^{3} / \mathrm{s}$ with errors of +150 and -75 percent would have a resulting error range of 1.25 to $12.5 \mathrm{ft}^{3} / \mathrm{s}$.

The standard errors of prediction for the equations across the eight regions had a minimum range of +26.9 to -21.2 percent for the $7 Q_{2}$ statistic in region 5 and a maximum range of +311 to -75.7 percent for the $1 Q_{10}$ statistic in region 7 . These error values represent the general predictive ability of the estimating equations; however, other factors could limit the applicability of the equations. It is important to note that because of the transformation from log to back to arithmetic units, the standard error values will always have larger positive values than negative values.

Because the zero-flow probability and low-flow estimating equations are based on regression analyses, the equations might not be reliable for sites where the basin-characteristic values are outside of the range of values that were used to develop the equations (table 5). In addition, using basin characteristic values near their extremes (maximum or minimum, table 5) might result in unreliable estimates. Figure 2 shows a "cloud of common values" for two basin characteristics. In this example, if the minimum value for mean annual precipitation and the maximum value for mean basin elevation were used, the combination would plot outside of the "cloud of common values," thus the corresponding equation might result in unreliable estimates. Generating basin-characteristic values by using datasets or processes other than those described in this study also will result in estimates of unknown reliability. The standard errors for each equation are only applicable if the datasets presented in table 1 are used to obtain the required basin characteristics.

The equations are not applicable for stream reaches affected by irrigation diversions and(or) returns, or dams that regulate streamflow. The Boise River downstream from Lucky Peak Lake, the Clearwater River downstream from Dworshak Reservoir, and the entire Snake River in Idaho are examples of stream reaches within the study area for which the estimating equations are not applicable. However, the equations could be used on regulated streams to provide an estimate of natural flow statistics for comparison with the regulated statistics, given that, as previously explained, all of the basin characteristics for the site fall within the ranges of those used to develop the equations.

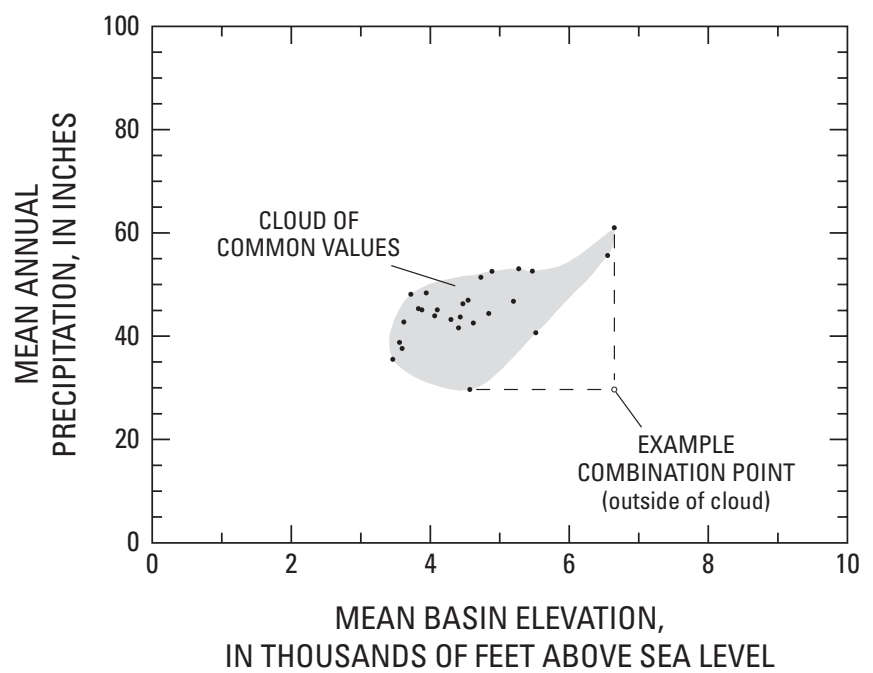

Figure 2. Joint distribution of two example basin characteristics, mean basin elevation and mean annual precipitation. 
Table 5. Range of values of basin characteristics used to estimate low-flow frequency statistics for unregulated streams in regions 1-8 in Idaho.

[Location of regions are shown in figure 1. Equation variables: $A$, drainage area, in square miles; $P$, mean annual precipitation, in inches; $D V$, developed land, in percentage of drainage area; $A G$, agricultural land, in percentage of drainage area; $B S$, basin slope, in percent; $W$, water, in percentage of drainage area; $R$, basin relief, in feet; $V$, surficial volcanic rocks, in percentage of drainage area; $S 50$, slopes greater than 50 percent, in percentage of drainage area]

\begin{tabular}{|c|c|c|c|c|c|c|c|c|c|}
\hline & \multicolumn{9}{|c|}{ Equation variables } \\
\hline \multicolumn{10}{|l|}{ Region 1} \\
\hline Maximum & $1,011.0$ & 54.3 & 3.59 & 23.2 & 46.4 & 6.69 & $5,866.9$ & 27.9 & 41.4 \\
\hline Minimum & 12.5 & 25.1 & .000 & .005 & 12.2 & .004 & $2,230.6$ & .000 & 1.04 \\
\hline \multicolumn{10}{|l|}{ Region 2} \\
\hline \multicolumn{10}{|l|}{ Region 3} \\
\hline Maximum & 674.9 & 30.1 & 18.6 & 91.6 & 35.4 & 0.258 & $5,098.9$ & 92.7 & 27.5 \\
\hline Minimum & 17.6 & 19.3 & .031 & 7.46 & 10.0 & .006 & $1,442.8$ & 14.5 & .018 \\
\hline \multicolumn{10}{|l|}{ Region 4} \\
\hline Maximum & $5,507.9$ & 65.6 & 0.126 & 18.4 & 57.2 & 1.04 & $8,364.5$ & 100.0 & 63.1 \\
\hline Minimum & 19.3 & 22.4 & .000 & .000 & 20.2 & .002 & $2,743.5$ & 27.1 & 3.47 \\
\hline \multicolumn{10}{|l|}{ Region 6} \\
\hline Maximum & $6,236.7$ & 42.3 & 0.385 & 9.27 & 66.2 & 1.19 & $9,419.7$ & 93.0 & 77.2 \\
\hline Minimum & 6.4 & 15.3 & .000 & .000 & 8.60 & .000 & $2,395.4$ & .000 & 1.36 \\
\hline \multicolumn{10}{|l|}{ Region 7} \\
\hline Maximum & 535.3 & 29.3 & 0.296 & 28.1 & 35.3 & 0.599 & $5,683.3$ & 100.0 & 28.5 \\
\hline Minimum & 7.4 & 12.3 & .000 & .000 & 10.1 & .000 & $1,681.7$ & .000 & .189 \\
\hline \multicolumn{10}{|l|}{ Region 8} \\
\hline Maximum & 874.8 & 56.0 & 0.176 & 70.7 & 53.2 & 3.83 & $6,232.1$ & 90.1 & 60.5 \\
\hline Minimum & 6.6 & 14.2 & .000 & .000 & 6.15 & .000 & $1,100.5$ & .000 & .002 \\
\hline
\end{tabular}

The estimating equations may not be applicable for streams that exhibit significant gains as a result of spring flow or significant losses as a result of channel seepage. The effects of headwater springs and other small springs that are representative of many or all streams in a particular region because of similar geologic conditions likely would be reflected in the equations for that region. The effects of larger springs which significantly affect streamflows likely would not be reflected in the equations. Similarly, the effects of small losses due to channel seepage which are representative of streams in a particular region likely would be reflected in the equations, while the effects of larger losses likely would not. In specific instances, user judgment may be required to decide if the particular ungaged site of interest is affected by factors similar to those that affected the gaging station data used to develop the relevant equations. For example, results for an ungaged site on the Lemhi River near Lemhi in region 6, which has fairly significant and highly variable streamflow gains and losses
(Donato, 1998), may be suspect since no mainstem Lemhi River gaging stations were used to develop the equations. However, if a gaging station from the Lemhi River or another river with similar characteristics were included, the equations likely would produce satisfactory results.

\section{Application of Regional Regression Method}

Three examples are given for using the equations to estimate low-flow frequency statistics for unregulated streams in Idaho. Example 1 addresses the basic ungaged site with the entire upstream drainage area located within the same region and no zero-flow probabilities, example 2 addresses the situation where zero-flow probability equations are used to estimate the probability of zero flows at a site (regions 4 , 6 , and 7, only) and example 3 addresses the situation where the drainage area of a specific site encompasses parts of two separate regions. 


\section{Example 1}

An estimate of the $7 Q_{2}$ low-flow statistic is required for a stream location in region 2 . The following required basin characteristics were determined for region 2 equations: $A, 2180.5 \mathrm{mi}^{2}$; and $P, 30.2 \mathrm{in}$. Since region 2 has no zero flow annual probability equations, the user would go directly to the low-flow frequency regression equations. Based on the basin-characteristic values, the estimated $7 Q_{2}$ statistic can be computed as follows:

$$
\begin{aligned}
& 7 Q_{2}=0.000153 A^{1.04} P^{1.92} \\
& 7 Q_{2}=0.000153(2180.5)^{1.04}(30.2)^{1.92} \\
& 7 Q_{2}=315 \mathrm{ft}^{3} / \mathrm{s}
\end{aligned}
$$

The predicted range of the actual values for this low-flow statistic, based on the range of the standard error of prediction given in table 4, is as follows:

$$
7 Q_{2}=176 \mathrm{ft}^{3} / \mathrm{s} \text { to } 562 \mathrm{ft}^{3} / \mathrm{s}(+78.9 \text { to }-44.1 \text { percent }) .
$$

\section{Example 2}

An estimate of the $7 Q_{10}$ low-flow statistic is required for a stream location in region 6 . The following required basin characteristics were determined for region 6 equations: $A$, $8.2 \mathrm{mi}^{2}$; and $P, 24.7 \mathrm{in}$; and $A G, 1.35$ percent. Based on these values, the probability of the 7-day low-flow equaling zero at this site is computed as follows:

$$
\begin{aligned}
& P_{7-\text { day }}=\frac{e^{(25.0-0.0156 A-1.27 P+0.899(A G+1))}}{1+e^{(25.0-0.0156 A-1.27 P+0.899(A G+1))}} \\
& P_{7 \text { day }}=\frac{e^{(25.0-0.0156(8.2)-1.27(24.7)+0.899(1.35+1))}}{1+e^{(25.0-0.0156(8.2)-1.27(24.7)+0.899(1.35+1))}} \\
& P_{7-\text { day }}=0.012
\end{aligned}
$$

Because the probability is less than 0.10 (1/10 for 10 year recurrence), the equation estimates that the 7-day low flow for this site is greater than zero. The estimated $7 Q_{10}$ statistic can then be computed as follows:

$$
\begin{aligned}
7 Q_{10} & =0.0000360 A^{1.06} P^{2.38} \\
7 Q_{10} & =0.0000360(8.2)^{1.06}(24.7)^{2.38} . \\
7 Q_{10} & =0.691 \mathrm{ft} 3 / \mathrm{s}
\end{aligned}
$$

The predicted range of the actual values for this low-flow statistic, based on the range of the standard error of prediction given in table 4, is as follows:

$$
7 Q_{10}=0.341 \mathrm{ft}^{3} / \mathrm{s} \text { to } 1.40 \mathrm{ft} 3 / \mathrm{s}(+103 \text { to }-50.7 \text { percent }) \text {. }
$$

\section{Example 3}

An estimate of the $30 Q_{5}$ low-flow statistic is required for a site in region 5 on a stream with a drainage basin encompassing parts of regions 5 and 6 . The recommended method for handling sites with portions of its drainage basin in two regions is as follows: (1) calculate values for the entire drainage basin by using equations from the first region, (2) calculate values for the entire drainage basin by using equations from the second region, and (3) average the two values on the basis of the proportion of drainage area in each region (Sando, 1998). The following required basin characteristics were determined for region 5 and 6 equations: $A, 5,153.0 \mathrm{mi}^{2} ; V, 78.5$ percent; and $P, 39.4$ in. The portion of the drainage area located in region 5 covers $1,622.0 \mathrm{mi}^{2}$ and the portion in region 6 covers $3,531.0 \mathrm{mi}^{2}$. The step to check for the probability of zero flow in region 6 was skipped because of the large portion of the drainage area in region 5 . Because the region boundaries were almost exclusively drawn along hydrologic boundaries, the occurrence of zero flows at sites that have portions of the drainage area in two regions is highly unlikely, but should be verified.

Region 5 calculations:

$$
\begin{aligned}
& 30 Q_{5}=0.000127 A^{1.04} P^{2.10} \\
& 30 Q_{5}=0.000127(5153.0)^{1.04}(39.4)^{2.10} . \\
& 30 Q_{5}=2,060 \mathrm{ft}^{3} / \mathrm{s}
\end{aligned}
$$

Region 6 calculations:

$$
\begin{aligned}
& 30 Q_{5}=0.000127 A^{1.04} P^{2.10} \\
& 30 Q_{5}=0.000127(5153.0)^{1.04}(39.4)^{2.10} . \\
& 30 Q_{5}=2,060 \mathrm{ft}^{3} / \mathrm{s}
\end{aligned}
$$

Area-weighted average:

$$
\begin{aligned}
& 30 Q_{5}=1,690 \mathrm{ft}^{3} / \mathrm{s}\left(\frac{1,622.0}{5,153.0}\right)+2,060 \mathrm{ft}^{3} / \mathrm{s}\left(\frac{3,531.0}{5,153.0}\right) . \\
& 30 Q_{5}=1,940 \mathrm{ft}^{3} / \mathrm{s}
\end{aligned}
$$




\section{Summary}

The USGS, in cooperation with the Idaho Department of Environmental Quality (IDEQ), used multiple linear regression analyses to develop equations that can be used for estimating the $1 Q_{10}, 7 Q_{2}, 7 Q_{10}$, and $30 Q_{5}$ low-flow frequency statistics at ungaged, unregulated sites on streams in Idaho. As part of this process, the relevant statistics were updated for all gaging stations in Idaho and some in adjacent States that, in general, had 10 or more years of record through water year 2003 and were unaffected by regulation and/or diversions. In regions of the State where one or more of these statistics are sometimes equal to zero, logistic regression analyses were used to develop equations for estimating the probability that the annual N-day low flow is equal to zero. Various physical and climatic characteristics of the drainage basins (basin characteristics) were used as the explanatory variables in each of the equations.

The logistic regression analyses in regions 4,6 , and 7 resulted in equations that were statistically significant for estimating the annual probability of zero flows for 1-, 7-, and 30-day periods. The final probability equations correctly predicted zero-flow values for 74 to 100 percent of the gaging stations used to develop the equations, depending on the region and the $\mathrm{N}$-day period. Although it is assumed that these gaging stations provide a good representation of zero-flow characteristics in each of the regions, any variability in the zero-flow characteristics within each region that was not represented may affect the predictive accuracy of the final equations. The zero-flow probability equations should be used for sites in regions 4, 6, and 7 before low-flow frequency statistics are estimated. If the resulting probability is greater than the non-exceedance probability for the statistic of interest, then the expected value for that statistic would be zero and the low-flow frequency equations should not be used. If the resulting probability is less than the non-exceedance probability for the statistic of interest, then the low-flow frequency equations should be used to estimate the value of the required statistic.

The equations for estimating low-flow frequency statistics had standard errors of prediction with a minimum range of +26.9 to -21.2 percent and a maximum range of +311 to -75.7 percent. In general, the $7 Q_{2}$ estimating equations exhibited the lowest standard errors, whereas the $1 Q_{10}$ equations exhibited the largest standard errors. The equations may not yield reliable results for sites with basin-characteristic values that are outside of the range of values used to develop the equations. The equations also are not applicable for sites on regulated streams or on streams that are affected by significant gains and(or) losses resulting from factors including spring flow, channel seepage, diversions, and irrigation returns. If desired, however, the equations could be used on regulated streams to provide an estimate of natural flow statistics for comparison with the regulated statistics.

\section{References Cited}

Berenbrock, Charles, 2002, Estimating the magnitude of peak flows at selected recurrence intervals for streams in Idaho: U.S. Geological Survey Water-Resources Investigations Report 02-4170, 59 p.

Bond, J.G., 1978, Geologic map of Idaho: Moscow, Idaho Bureau of Mines and Geology, 1 sheet, scale 1:500,000.

Daly, C., and Taylor, G., 1998, Western United States average monthly or annual precipitation, 1961-90, Oregon: Portland, Water and Climate Center of the Natural Resources Conservation Service, accessed DATE at URL: http://www. ocs.orst.edu/prism/prism new.html.

Donato, M.M., 1998, Surface-water/ground-water relations in the Lemhi River Basin, East-Central Idaho: U.S. Geological Survey Water-Resources Investigations Report 98-4185, $20 \mathrm{p}$.

Emmett, W.W., 1975, The channels and waters of the upper Salmon River area, Idaho: U.S. Geological Survey Professional Paper 870-A, 115 p.

Environmental Systems Research Institute, Inc., 2005, ArcGIS desktop help: accessed June, 2005, at URL: http://webhelp. esri.com/arcgisdesktop/9.1.

Haan, C.T., 1977, Statistical methods in hydrology: Ames, Iowa State University Press, 378 p.

Harenberg, W.A., 1980, Using channel geometry to estimate flood flows at ungaged sites in Idaho: U.S. Geological Survey Water-Resources Investigations 80-32, 39 p.

Hedman, E.R., and Osterkamp, W.R., 1982, Streamflow characteristics related to channel geometry of streams in western United States: U.S. Geological Survey Water-Supply Paper 2193, 17 p.

Helsel, D.R., and Hirsch, R.M., 1992, Statistical methods in water resources: New York, Elsevier Science Publishing Company, Inc., 522 p.

Horn, D.R., 1988, Annual flow statistics for ungaged streams in Idaho: American Society of Civil Engineers, Journal of Irrigation and Drainage Engineering, v. 114, no. 3, p. 463-474.

Hortness, J.E., and Berenbrock, Charles, 2001, Estimating monthly and annual streamflow statistics at ungaged sites in Idaho: U.S. Geological Survey Water-Resources Investigations Report 0-4093, 36 p.

Hortness, J.E., and Berenbrock, Charles, 2003, Estimating the magnitude of bankfull flows for streams in Idaho: U.S. Geological Survey Water-Resources Investigations Report 03-4261, 36 p.

Hosmer, D.W., and Lemeshow, S., 2000, Applied logistic regression: New York, John Wiley \& Sons, Inc., 373 p.

Kjelstrom, L.C., 1998, Methods for estimating selected flow-duration and flood-frequency characteristics at ungaged sites in central Idaho: U.S. Geological Survey Water-Resources Investigations Report 94-4120, 10 p. 
Kjelstrom, L.C., and Moffatt, R.L., 1981, A method of estimating flood-frequency parameters for streams in Idaho: U.S. Geological Survey Open-File Report 81-909, 99 p.

Kjelstrom, L.C., Stone, M.A.J., and Harenberg, W.A., 1995, Statistical summaries of streamflow data for selected gaging stations in Idaho and western Wyoming through September 1990 - Volume 2: Gaging stations with 5 to 9 years of record or that measure discharge from springs: U.S. Geological Survey Water-Resources Investigations Report 94-4070, 94 p.

Kjelstrom, L.C., Stone, M.A.J., and Harenberg, W.A., 1996, Statistical summaries of streamflow data for selected gaging stations in Idaho and adjacent States through September 1990 - Volume 1. Gaging stations with 10 or more years of record: U.S. Geological Survey Water-Resources Investigations Report 94-4069, 533 p.

Koltun, G.F., and Schwartz, R.R., 1986, Multiple-regression equations for estimating low flows at ungaged stream sites in Ohio: U.S. Geological Survey Water-Resources Investigations Report 86-4354, 39 p., 6 pls.

Lipscomb, S.W., 1998, Hydrologic classification and estimation of basin and hydrologic characteristics of subbasins in central Idaho: U.S. Geological Survey Professional Paper 1604, 49 p.

Ludwig, A.H., and Tasker, G.D., 1993, Regionalization of low-flow characteristics of Arkansas streams: U.S. Geological Survey Water-Resources Investigations Report 93-4013, 19 p.

Molnau, M., 1995, Mean annual precipitation, 1961-1990, Idaho: Moscow, University of Idaho, Agricultural Engineering Department, State Climate Program, scale 1:1,000,000. Available at URL: http://snow.ag.uidaho.edu/ Climate/reports.html.

National Oceanic and Atmospheric Administration, 1971, Climates of the states, climate of Idaho, in Climatography of the United States: Silver Spring, Md., no. 60-10, 18 p.

Parrett, Charles, and Johnson, D.R., 2004, Methods for estimating flood frequency in Montana based on data through water year 1998: U.S. Geological Survey Water-Resources Investigations Report 03-4308, 101 p., 1 pl.

Pope, B.F., Tasker, G.D., and Robbins, J.C., 2001, Estimating the magnitude and frequency of floods in rural basins of North Carolina_revised: U.S. Geological Survey Water-Resources Investigations Report 01-4207, 44 p.

Quillian, E.W., and Harenberg, W.A., 1982, An evaluation of Idaho stream-gaging networks: U.S. Geological Survey Open-File Report 82-865, 57 p.
Ries, K.G., and Friesz, P.J., 2000, Methods for estimating low-flow statistics for Massachusetts streams: U.S. Geological Survey Water-Resources Investigations Report 00-4135, $81 \mathrm{p}$.

Riggs, H.C., 1968, Some statistical tools in hydrology: U.S. Geological Survey Techniques of Water-Resources Investigations, Book 4, Chap. A1, 39 p.

Riggs, H.C., 1972, Low-flow investigations: U.S. Geological Survey Techniques of Water-Resources Investigations, Book 4, Chap. B1, 18 p.

Ross, S.H., and Savage, C.N., 1967, Idaho earth science: Moscow, Idaho Bureau of Mines and Geology, 285 p.

Sando, S.K., 1998, Techniques for estimating peak-flow magnitude and frequency relations for South Dakota streams: U.S. Geological Survey Water-Resources Investigations Report 98-4055, 48 p.

Statit Software, 2005, Statit Custom QC: accessed January 2005, at URL: http://www.statit.com/statitcustomqc/ customqc default.htm.

Tasker, G.D., 1989, Regionalization of low flow characteristics using logistic and GLS regression, in Kavvas, M.L., ed., New directions for surface water modeling: IAHS Publication No. 181, p. 323-331.

Tasker, G.D., and Stedinger, J.R., 1989, An operational GLS model for hydrologic regression: Journal of Hydrology, v. 3, p. 361-375.

Thomas, C.A., Harenberg, W.A., and Anderson, J.M., 1973, Magnitude and frequency of floods in small drainage basins in Idaho: U.S. Geological Survey Water-Resources Investigations Report 7-73, 61 p.

Thomas, B.E., Hjalmarson, H.W., and Waltemeyer, S.D., 1994, Methods for estimating magnitude and frequency of floods in the Southwestern United States: U.S. Geological Survey Open-File Report 93-419, 211 p.

U.S. Geological Survey, 1995, Major lithology_Spokane, Washington: accessed July 2004, at URL: http://www. icbemp.gov/spatial/min.

U.S. Geological Survey, 1998, Water Resources Applications Software, GLSNET: accessed February 2005, at URL: http://water.usgs.gov/software/glsnet.html.

Vogelmann, J.E., Sohl, T.L., Campbell, P.V., and Shaw, D.M., 1998, Regional land cover characterization using Landsat Thematic Mapper data and ancillary data sources: Environmental Monitoring and Assessment, v. 51, p. 415-428, accessed July 2004, at URL: http://edcwww. cr.usgs.gov/programs/lccp. 
Table 6. Selected information for gaging stations used to estimate low-flow frequency statistics for unregulated streams in regions 1-8 in Idaho.

[Location of gaging stations and regions are shown in figure 1. Gaging station name: ID, Idaho; WA, Washington; MT, Montana; OR, Oregon; UT, Utah; NV, Nevada; WY, Wyoming. Water year: The 12-month period from October 1 through September 20, designated by the calendar year in which it ends]

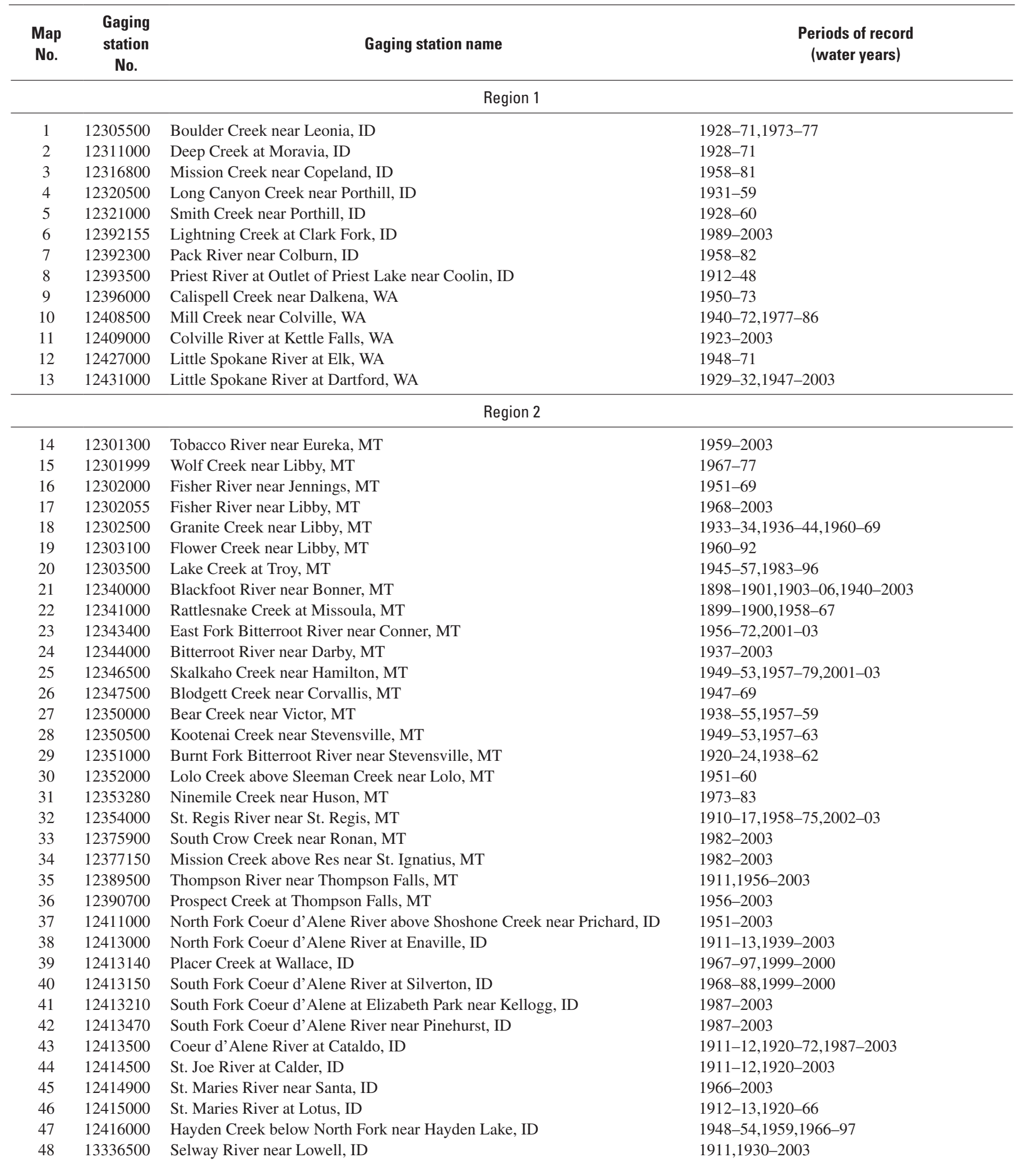


Table 6. Selected information for gaging stations used to estimate low-flow frequency statistics for unregulated streams in regions 1-8 in Idaho.Continued

[Location of gaging stations and regions are shown in figure 1. Gaging station name: ID, Idaho; WA, Washington; MT, Montana; OR, Oregon; UT, Utah; NV, Nevada; WY, Wyoming. Water year: The 12-month period from October 1 through September 20, designated by the calendar year in which it ends]

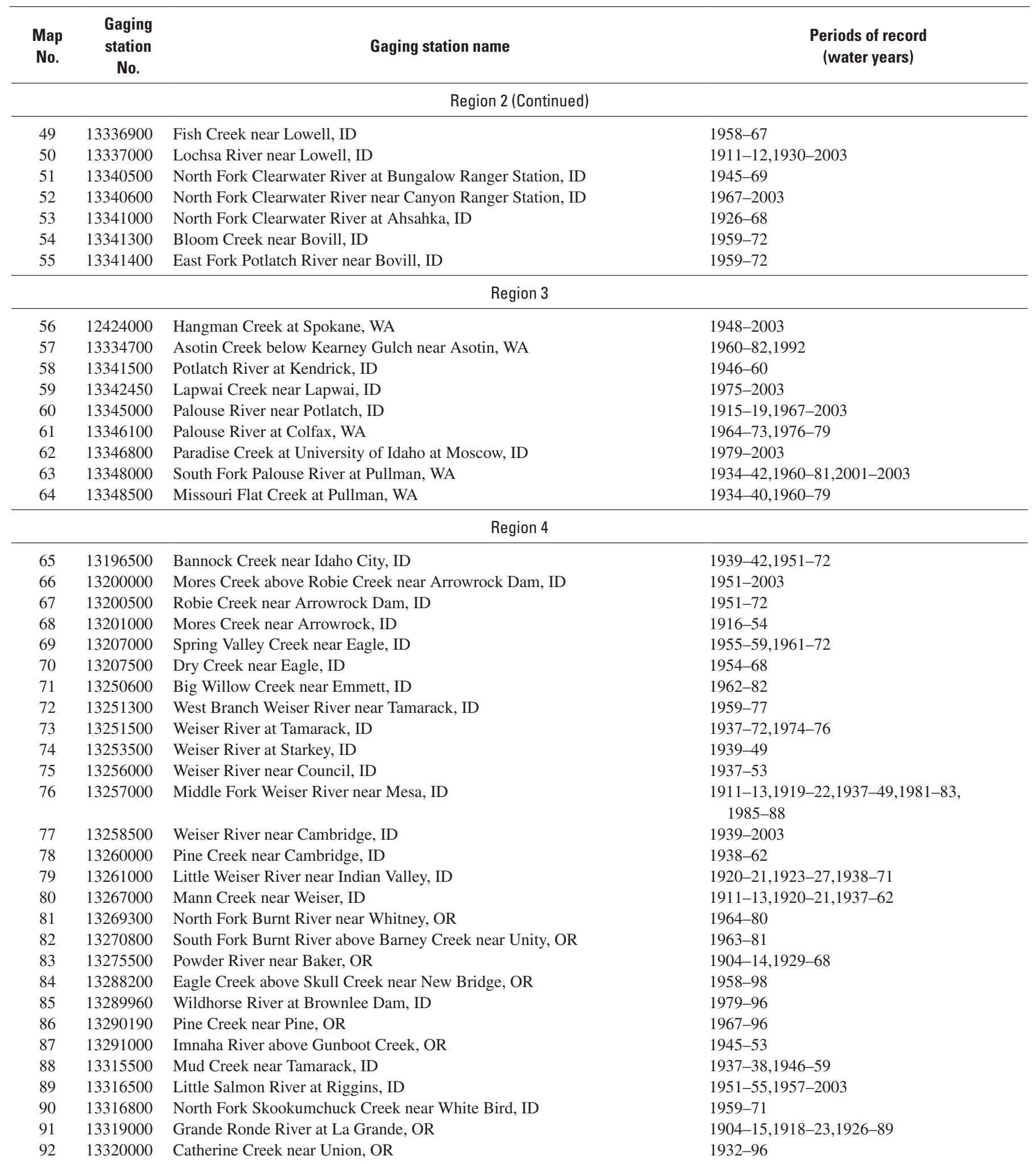


Table 6. Selected information for gaging stations used to estimate low-flow frequency statistics for unregulated streams in regions 1-8 in Idaho.Continued

[Location of gaging stations and regions are shown in figure 1. Gaging station name: ID, Idaho; WA, Washington; MT, Montana; OR, Oregon; UT, Utah; NV, Nevada; WY, Wyoming. Water year: The 12-month period from October 1 through September 20, designated by the calendar year in which it ends]

\begin{tabular}{|c|c|c|c|}
\hline $\begin{array}{l}\text { Map } \\
\text { No. }\end{array}$ & $\begin{array}{c}\text { Gaging } \\
\text { station } \\
\text { No. }\end{array}$ & Gaging station name & $\begin{array}{l}\text { Periods of record } \\
\text { (water years) }\end{array}$ \\
\hline \multicolumn{4}{|c|}{ Region 4 (Continued) } \\
\hline 93 & 13323600 & Indian Creek near Imbler, OR & $1938-50$ \\
\hline 94 & 13325500 & Wallowa River above Wallowa Lake near Joseph, OR & 1924-33 \\
\hline 95 & 13329500 & Hurricane Creek near Joseph, OR & $1915,1924-78$ \\
\hline 97 & 13330500 & Bear Creek near Wallowa, OR & $1915,1924-85,1995-2003$ \\
\hline 98 & 13331500 & Minam River at Minam, OR & $1912-14,1965-2003$ \\
\hline 99 & 13337500 & South Fork Clearwater River near Elk City, ID & $1945-74,2002-03$ \\
\hline 100 & 13338000 & South Fork Clearwater River near Grangeville, ID & $1911-16,1923-63$ \\
\hline 101 & 13338500 & South Fork Clearwater River at Stites, ID & $1912,1965-2003$ \\
\hline 102 & 13339000 & Clearwater River at Kamiah, ID & 1910-66 \\
\hline \multicolumn{4}{|c|}{ Region 5} \\
\hline 107 & 13135500 & Big Wood River near Ketchum, ID & $1948-72$ \\
\hline 108 & 13136500 & Warm Springs Creek at Guyer Hot Springs near Ketchum, ID & $1941-58$ \\
\hline 109 & 13139500 & Big Wood River at Hailey, ID & $1889-90,1915-2003$ \\
\hline 110 & 13141000 & Big Wood River near Bellevue, ID & $1911-96$ \\
\hline 111 & 13185000 & Boise River near Twin Springs, ID & $1911-2003$ \\
\hline 112 & 13186000 & South Fork Boise River near Featherville, ID & $1945-2003$ \\
\hline 113 & 13186500 & Lime Creek near Bennett, ID & $1945-56$ \\
\hline 114 & 13187000 & Fall Creek near Anderson Ranch Dam, ID & $1945-56$ \\
\hline 115 & 13235000 & South Fork Payette River at Lowman, ID & $1941-2003$ \\
\hline 116 & 13240000 & Lake Fork Payette River above Jumbo Creek near McCall, ID & $1946-2003$ \\
\hline 124 & 13309000 & Bear Valley Creek near Capehorn, ID & $1922-60$ \\
\hline 125 & 13309220 & Middle Fork Salmon R at Middle Fork Lodge nr Yellow Pine, ID & $1973-81,1999-2003$ \\
\hline 126 & 13310000 & Big Creek near Big Creek, ID & $1945-59$ \\
\hline 127 & 13310199 & Middle Fork Salmon R at mouth near Shoup, ID & 1994-2003 \\
\hline 128 & 13310500 & South Fork Salmon River near Knox, ID & $1929-61$ \\
\hline 129 & 13310700 & South Fork Salmon River near Krassel Ranger Station, ID & $1967-82,1985-86,1989-2003$ \\
\hline 130 & 13311000 & East Fork South Fork Salmon River at Stibnite, ID & $1928-43,1983-97$ \\
\hline 131 & 13311500 & East Fork South Fork Salmon River near Stibnite, ID & $1928-41$ \\
\hline 132 & 13312000 & East Fork South Fork Salmon River near Yellow Pine, ID & $1928-43$ \\
\hline 133 & 13313000 & Johnson Creek at Yellow Pine, ID & $1928-2003$ \\
\hline 134 & 13313500 & Secesh River near Burgdorf, ID & $1943-52$ \\
\hline 135 & 13314000 & South Fork Salmon River near Warren, ID & $1931-43$ \\
\hline 136 & 13314300 & South Fork Salmon River at mouth nr Mackay Bar, ID & $1994-2003$ \\
\hline 137 & 13315000 & Salmon River near French Creek, ID & $1945-56$ \\
\hline
\end{tabular}


Table 6. Selected information for gaging stations used to estimate low-flow frequency statistics for unregulated streams in regions 1-8 in Idaho.Continued

[Location of gaging stations and regions are shown in figure 1. Gaging station name: ID, Idaho; WA, Washington; MT, Montana; OR, Oregon; UT, Utah; NV, Nevada; WY, Wyoming. Water year: The 12-month period from October 1 through September 20, designated by the calendar year in which it ends]

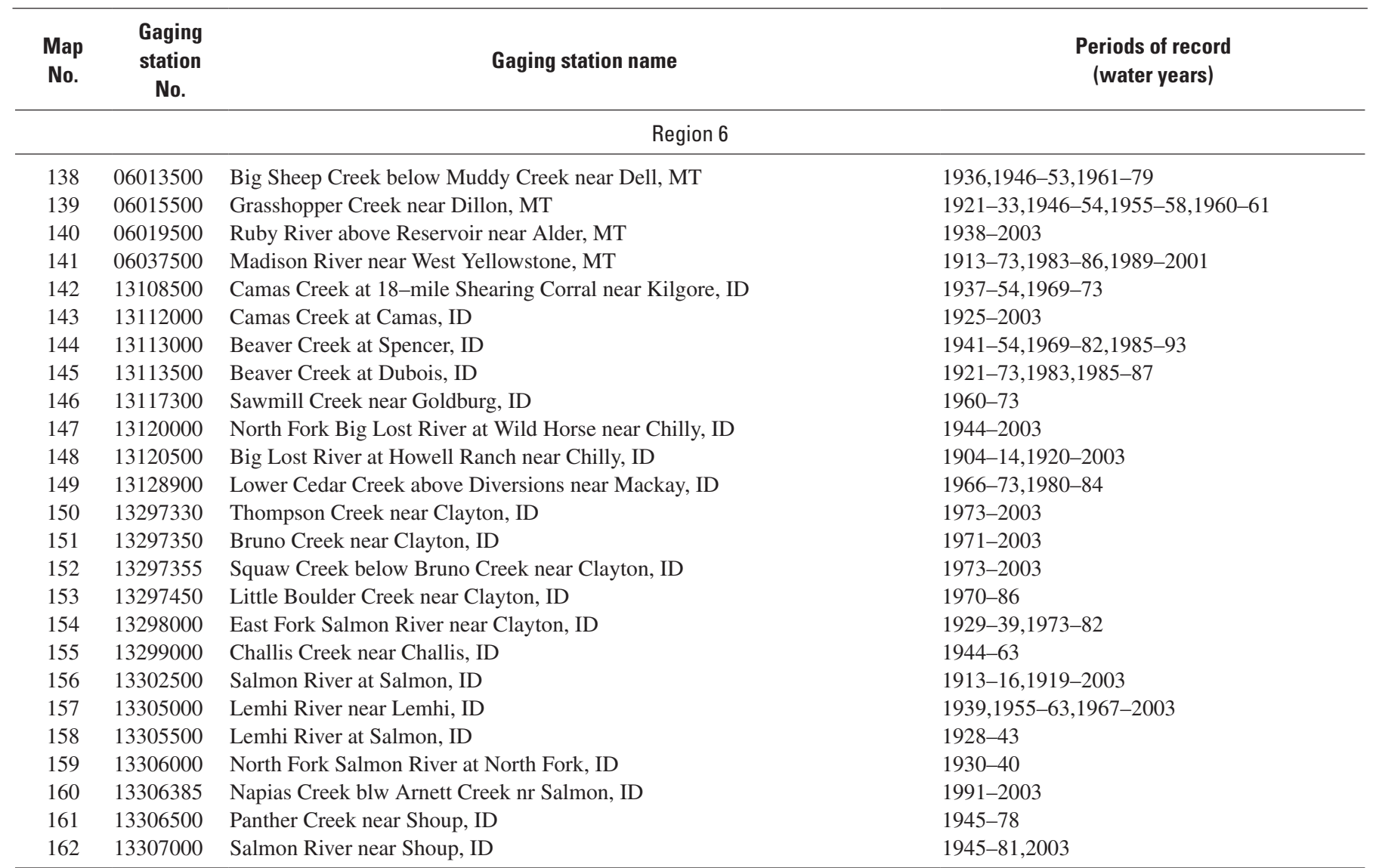

\begin{tabular}{llll}
\hline & & & \multicolumn{2}{l}{ Region 7 } & \\
\hline 163 & 10119000 & Little Malad River above Elkhorn Reservoir near Malad City, ID & $1911-13,1932,1941-69$ \\
164 & 10172940 & Dove Creek near Park Valley, UT & $1959-68,1971-73$ \\
165 & 10315500 & Marys River above Hot Springs Creek near Deeth, NV & $1944-80,1982-2003$ \\
166 & 10329500 & Martin Creek near Paradise Valley, NV & $1922-2003$ \\
167 & 10352500 & McDermitt Creek near McDermitt, NV & $1949-84,1985-2003$ \\
168 & 10353000 & East Fork Quinn River near McDermitt, NV & $1949-82$ \\
169 & 10396000 & Donner Und Blitzen River near Frenchglen, OR & $1911-21,1938-2003$ \\
170 & 10406500 & Trout Creek near Denio, NV & $1933-91$ \\
171 & 13057940 & Willow Creek below Tex Creek near Ririe, ID & $1977-79,1986-2003$ \\
172 & 13075000 & Marsh Creek near McCammon, ID & $1954-2003$ \\
173 & 13077700 & George Creek near Yost, UT & $1959-89$ \\
174 & 13079100 & Cassia Creek abv Stinson Creek nr Elba, ID & $1965-75$ \\
175 & 13092000 & Rock Creek near Rock Creek, ID & $1910-13,1939,1944-74$ \\
176 & 13154000 & Clover Creek below Calf Creek near Bliss, ID & $1938-43,1957-62$ \\
177 & 13155300 & Little Canyon Creek at Stout Crossing near Glenns Ferry, ID & $1966-71$ \\
178 & 13161500 & Bruneau River at Rowland, NV & $1913-18,1967-2003$ \\
179 & 13162500 & East Fork Jarbidge River near Three Creek, ID & $1929-33,1954-71$ \\
180 & 13169500 & Big Jacks Creek near Bruneau, ID & $1939-50,1965-2003$ \\
181 & 13170000 & Little Jacks Creek near Bruneau, ID & $1939-50$ \\
182 & 13172680 & Reynolds Creek at Tollgate near Reynolds, ID & $1966-93$ \\
183 & 13172720 & Macks Creek near Reynolds, ID & $1964-91$ \\
184 & 13172735 & Salmon Creek near Reynolds, ID & $1964-99$ \\
185 & 13172740 & Reynolds Creek at Outlet near Reynolds, ID & $1963-93$ \\
186 & 13176000 & Owyhee River above China Diversion Dam near Owyhee, NV
\end{tabular}


Table 6. Selected information for gaging stations used to estimate low-flow frequency statistics for unregulated streams in regions 1-8 in Idaho.Continued

[Location of gaging stations and regions are shown in figure 1. Gaging station name: ID, Idaho; WA, Washington; MT, Montana; OR, Oregon; UT, Utah; NV, Nevada; WY, Wyoming. Water year: The 12-month period from October 1 through September 20, designated by the calendar year in which it ends]

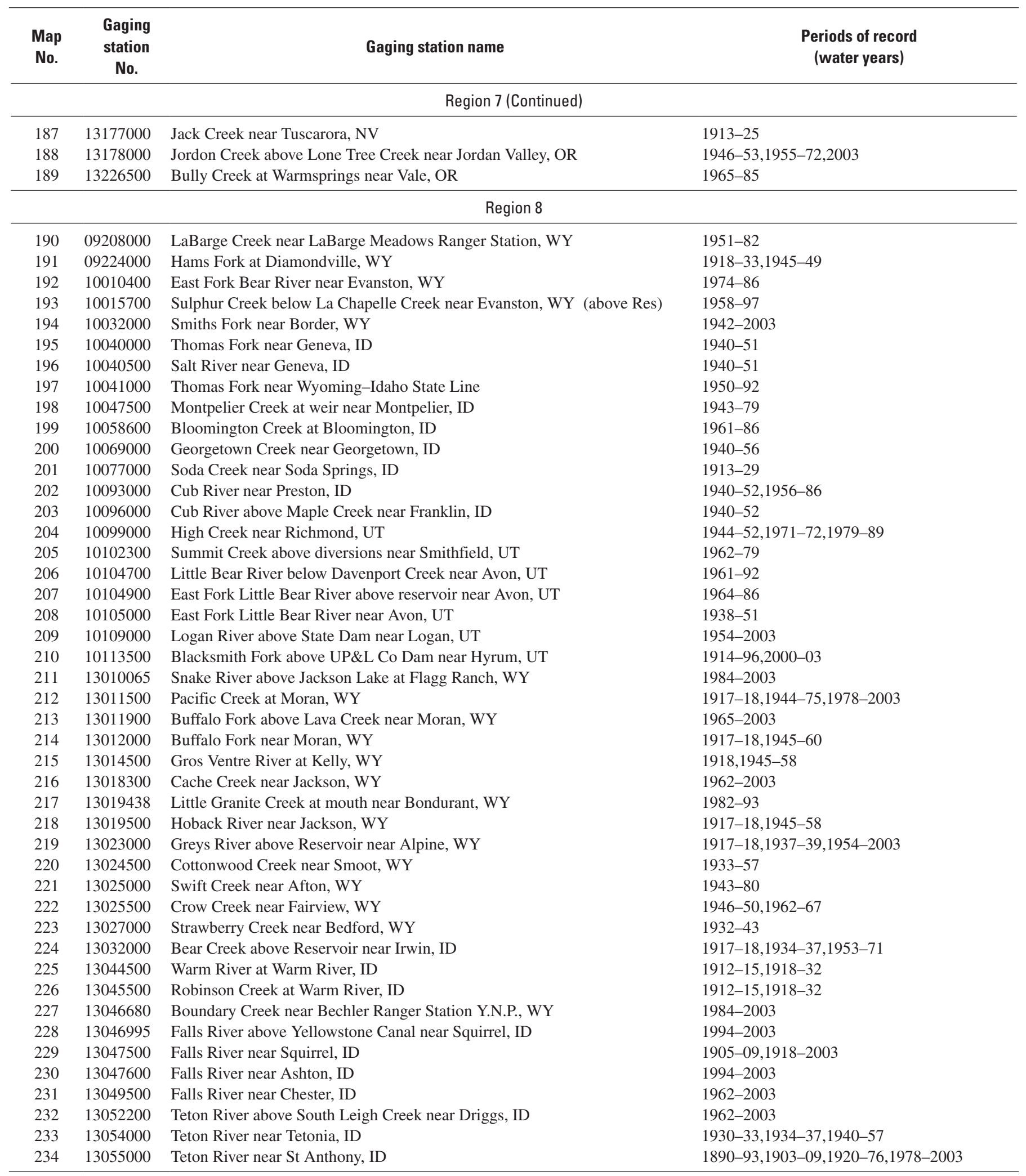


Table 7

Table 7. Low-flow frequency statistics for streamflow-gaging stations used in low-flow regression analyses for unregulated streams in regions 1-8 in Idaho.

$\left[1 Q_{10}, 1\right.$-day, 10 -year low flow; $7 Q_{10}, 7$-day, 10 -year flow; $7 Q_{2}, 7$-day, 2-year low flow; $30 Q_{5}, 30$-day, 5-year low flow $]$

\begin{tabular}{|c|c|c|c|c|c|c|c|c|c|}
\hline $\begin{array}{c}\text { Gaging } \\
\text { station No. }\end{array}$ & $10_{10}$ & $70_{10}$ & $70_{2}$ & $30 Q_{5}$ & $\begin{array}{c}\text { Gaging } \\
\text { station No. }\end{array}$ & $10_{10}$ & $70_{10}$ & $70_{2}$ & $30 a_{5}$ \\
\hline \multicolumn{5}{|c|}{ Region 1} & \multicolumn{5}{|c|}{ Region 3} \\
\hline 12305500 & 4.42 & 5.07 & 9.18 & 7.56 & 12424000 & 2.69 & 2.95 & 9.15 & 5.18 \\
\hline 12311000 & 7.83 & 8.65 & 13.0 & 11.44 & 13334700 & 23.3 & 26.6 & 32.7 & 32.4 \\
\hline 12316800 & 1.81 & 1.94 & 3.54 & 3.13 & 13341500 & 5.00 & 5.49 & 7.81 & 7.20 \\
\hline 12320500 & 2.82 & 3.40 & 6.25 & 4.92 & 13342450 & 1.43 & 1.61 & 3.93 & 2.86 \\
\hline 12321000 & 5.15 & 5.65 & 11.0 & 9.46 & 13345000 & .956 & 1.81 & 6.20 & 4.26 \\
\hline 12392155 & 2.20 & 2.50 & 11.4 & 2.47 & 13346100 & .200 & .287 & 3.20 & 1.63 \\
\hline 12392300 & 18.6 & 19.5 & 28.3 & 26.3 & 13346800 & .075 & .116 & .186 & .244 \\
\hline 12393500 & 142 & 145 & 215 & 176 & 13348000 & .494 & .627 & 1.77 & 1.06 \\
\hline 12396000 & 3.86 & 6.10 & 9.28 & 9.68 & 13348500 & .000 & .000 & .105 & .012 \\
\hline 12408500 & 4.96 & 5.54 & 8.47 & 7.64 & \multicolumn{5}{|c|}{ Region 4} \\
\hline 12409000 & 15.5 & 21.1 & 61.9 & 39.6 & 13196500 & 0.155 & 0.168 & 0.313 & 0.240 \\
\hline 12427000 & 31.0 & 34.8 & 40.3 & 38.6 & 13200000 & 9.67 & 10.4 & 25.6 & 17.4 \\
\hline 12431000 & 84.0 & 87.2 & 123 & 104 & 13200500 & .000 & .045 & .312 & .156 \\
\hline \multicolumn{5}{|c|}{ Region 2} & 13201000 & 12.1 & 12.7 & 26.6 & 19.0 \\
\hline 12301300 & 30.5 & 37.7 & 61.8 & 57.3 & 13207000 & .000 & .000 & .000 & .000 \\
\hline 12301999 & 3.22 & 3.80 & 6.81 & 5.70 & 13207500 & .000 & .000 & .099 & .045 \\
\hline 12302000 & 63.4 & 75.1 & 95.9 & 91.5 & 13250600 & 1.76 & 2.16 & 2.87 & 2.82 \\
\hline 12302055 & 48.5 & 59.8 & 85.4 & 79.5 & 13251300 & .475 & .572 & .800 & .753 \\
\hline 12302500 & 4.60 & 5.06 & 7.59 & 7.55 & 13251500 & 1.48 & 3.12 & 4.73 & 4.54 \\
\hline 12303100 & 3.55 & 3.84 & 4.90 & 4.63 & 13253500 & 10.2 & 10.4 & 14.6 & 12.8 \\
\hline 12303500 & 61.2 & 76.2 & 108 & 94.5 & 13256000 & 28.4 & 33.4 & 44.7 & 47.5 \\
\hline 12340000 & 230 & 284 & 390 & 402 & 13257000 & .000 & .000 & 1.054 & .396 \\
\hline 12341000 & .596 & .859 & 4.65 & 2.84 & 13258500 & 25.7 & 29.6 & 61.8 & 47.9 \\
\hline 12343400 & 29.2 & 41.0 & 60.8 & 64.2 & 13260000 & 0.991 & 1.29 & 2.41 & 2.15 \\
\hline 12344000 & 97.9 & 122 & 173 & 167 & 13261000 & 4.94 & 5.60 & 8.50 & 7.78 \\
\hline 12346500 & 14.0 & 16.5 & 19.3 & 20.6 & 13267000 & .185 & .258 & 1.24 & .874 \\
\hline 12347500 & 2.08 & 2.34 & 5.15 & 4.25 & 13269300 & .210 & .246 & .646 & .494 \\
\hline 12350000 & 1.08 & 1.43 & 3.06 & 2.76 & 13270800 & 13.0 & 14.6 & 17.6 & 17.6 \\
\hline 12350500 & 3.06 & 3.75 & 7.95 & 6.72 & 13275500 & .40 & .70 & 4.86 & 2.25 \\
\hline 12351000 & 4.92 & 7.17 & 11.1 & 11.9 & 13288200 & 44.2 & 53.1 & 69.6 & 67.5 \\
\hline 12352000 & 8.53 & 9.77 & 20.5 & 15.5 & 13289960 & 9.11 & 9.61 & 18.8 & 13.3 \\
\hline 12353280 & 12.4 & 14.1 & 19.9 & 18.5 & 13290190 & 18.0 & 18.9 & 33.1 & 25.2 \\
\hline 12354000 & 50.5 & 65.2 & 86.2 & 83.9 & 13291000 & 21.3 & 31.3 & 48.4 & 47.1 \\
\hline 12375900 & 3.92 & 4.56 & 5.53 & 5.35 & 13315500 & 1.01 & 1.05 & 1.31 & 1.31 \\
\hline 12377150 & 5.94 & 6.69 & 7.78 & 7.65 & 13316500 & 97.5 & 111 & 153 & 135 \\
\hline 12389500 & 73.5 & 93.4 & 128 & 123 & 13316800 & .183 & .211 & .768 & .547 \\
\hline 12390700 & 29.5 & 30.8 & 42.7 & 36.4 & 13319000 & 7.58 & 8.95 & 18.2 & 14.6 \\
\hline 12411000 & 52.8 & 58.6 & 79.6 & 75.5 & 13320000 & 12.6 & 15.9 & 21.4 & 20.7 \\
\hline 12413000 & 144 & 164 & 220 & 207 & 13323600 & 1.50 & 1.58 & 3.06 & 2.37 \\
\hline 12413140 & .901 & 1.07 & 3.17 & 2.33 & 13325500 & 15.3 & 15.6 & 22.6 & 19.7 \\
\hline 12413150 & 26.6 & 31.6 & 42.2 & 41.8 & 13329500 & 8.37 & 9.34 & 14.4 & 12.5 \\
\hline 12413210 & 40.3 & 48.6 & 60.3 & 56.3 & 13330000 & 15.1 & 17.5 & 25.9 & 23.2 \\
\hline 12413470 & 61.6 & 70.4 & 90.3 & 82.7 & 13330500 & 6.03 & 6.54 & 9.83 & 8.54 \\
\hline 12413500 & 215 & 238 & 317 & 292 & 13331500 & 24.9 & 36.8 & 62.7 & 57.0 \\
\hline 12414500 & 185 & 233 & 333 & 313 & 13337500 & 19.3 & 21.9 & 31.7 & 29.9 \\
\hline 12414900 & 28.3 & 32.9 & 45.3 & 42.4 & 13338000 & 48.6 & 74.8 & 118 & 112 \\
\hline 12415000 & 24.1 & 28.7 & 45.1 & 39.1 & 13338500 & 80.3 & 111 & 152 & 145 \\
\hline 12416000 & 2.39 & 2.56 & 3.59 & 3.39 & 13339000 & 481 & 672 & 1,090 & 992 \\
\hline 13336500 & 255 & 333 & 496 & 463 & 13339500 & 18.9 & 21.1 & 31.8 & 29.0 \\
\hline 13336900 & 22.9 & 23.3 & 29.8 & 28.0 & 13340000 & 584 & 768 & 1,120 & 1,040 \\
\hline 13337000 & 199 & 243 & 358 & 335 & 14010000 & 82.2 & 83.5 & 98.7 & 91.1 \\
\hline 13340500 & 328 & 405 & 587 & 541 & 14011000 & 1.18 & 1.47 & 2.45 & 2.16 \\
\hline 13340600 & 330 & 477 & 629 & 641 & & & & & \\
\hline 13341000 & 525 & 645 & 1000 & 935 & & & & & \\
\hline 13341300 & .496 & .546 & .729 & .677 & & & & & \\
\hline 13341400 & 4.08 & 4.36 & 6.01 & 5.51 & & & & & \\
\hline
\end{tabular}


Table 7. Low-flow frequency statistics for streamflow-gaging stations used in low-flow regression analyses for unregulated streams in regions 1-8 in Idaho.-Continued

$\left[1 Q_{10}, 1\right.$-day, 10 -year low flow; $7 Q_{10}, 7$-day, 10 -year flow; $7 Q_{2}, 7$-day, 2-year low flow; 30 $Q_{5}, 30$-day, 5-year low flow $]$

\begin{tabular}{|c|c|c|c|c|c|c|c|c|c|}
\hline $\begin{array}{c}\text { Gaging } \\
\text { station No. }\end{array}$ & $1 a_{10}$ & $70_{10}$ & $70_{2}$ & $30 Q_{5}$ & $\begin{array}{c}\text { Gaging } \\
\text { station No. }\end{array}$ & $10_{10}$ & $70_{10}$ & $70_{2}$ & $30 O_{5}$ \\
\hline \multicolumn{5}{|c|}{ Region 5} & \multicolumn{5}{|c|}{ Region 7} \\
\hline 13135500 & 22.5 & 34.0 & 39.1 & 40.5 & 10119000 & 6.13 & 6.42 & 13.44 & 9.81 \\
\hline 13136500 & 19.0 & 24.3 & 27.4 & 27.7 & 10172940 & .083 & .083 & .140 & .104 \\
\hline 13139500 & .412 & .752 & 47.3 & 6.89 & 10315500 & .365 & .402 & 1.06 & .701 \\
\hline 13141000 & 22.2 & 23.4 & 44.6 & 32.4 & 10329500 & 3.64 & 3.80 & 5.23 & 4.64 \\
\hline 13185000 & 163 & 214 & 279 & 268 & 10352500 & .000 & .000 & 1.09 & .239 \\
\hline 13186000 & 101 & 126 & 171 & 159 & 10353000 & .484 & .581 & 1.30 & .936 \\
\hline 13186500 & 6.38 & 10.2 & 16.5 & 14.5 & 10396000 & 14.9 & 20.7 & 30.6 & 28.7 \\
\hline 13187000 & 10.1 & 11.1 & 13.3 & 12.5 & 10406500 & .605 & .695 & 2.44 & 1.49 \\
\hline 13235000 & 158 & 198 & 251 & 244 & 13057940 & 4.86 & 5.30 & 18.1 & 9.57 \\
\hline 13240000 & 1.89 & 6.70 & 12.1 & 11.0 & 13075000 & 20.3 & 23.9 & 38.3 & 33.1 \\
\hline 13292500 & 2.94 & 3.05 & 7.04 & 4.75 & 13077700 & 1.17 & 1.27 & 1.65 & 1.54 \\
\hline 13293000 & 11.3 & 11.5 & 14.8 & 13.5 & 13079100 & 0.251 & .280 & .670 & .458 \\
\hline 13295000 & 44.5 & 46.4 & 64.1 & 57.4 & 13092000 & 4.23 & 4.50 & 6.81 & 5.92 \\
\hline 13295500 & 165 & 179 & 272 & 229 & 13154000 & .000 & .000 & .145 & .072 \\
\hline 13296000 & 19.8 & 29.2 & 37.9 & 34.9 & 13155300 & .016 & .092 & .299 & .228 \\
\hline 13296500 & 239 & 262 & 351 & 318 & 13161500 & 3.47 & 3.72 & 8.57 & 5.85 \\
\hline 13308500 & 46.3 & 49.5 & 61.5 & 57.1 & 13162500 & 3.68 & 5.00 & 7.45 & 6.52 \\
\hline 13309000 & 59.4 & 64.3 & 81.9 & 72.8 & 13169500 & .000 & .000 & .000 & .000 \\
\hline 13309220 & 202 & 268 & 358 & 364 & 13170000 & .000 & .000 & .000 & .000 \\
\hline 13310000 & 70.8 & 94.3 & 108 & 109 & 13172680 & .000 & .000 & .202 & .025 \\
\hline 13310199 & 382 & 561 & 714 & 698 & 13172720 & .000 & .000 & .016 & .006 \\
\hline 13310500 & 21.1 & 23.0 & 32.5 & 28.2 & 13172735 & .000 & .000 & .016 & .000 \\
\hline 13310700 & 66.5 & 80.8 & 107 & 97.9 & 13172740 & .079 & .195 & .848 & .490 \\
\hline 13311000 & 4.41 & 4.77 & 6.17 & 5.48 & 13176000 & 5.98 & 6.97 & 16.5 & 12.0 \\
\hline 13311500 & 10.2 & 11.2 & 12.3 & 12.0 & 13177000 & .958 & .955 & 1.60 & 1.42 \\
\hline 13312000 & 27.7 & 27.9 & 35.1 & 31.5 & 13178000 & .475 & .940 & 1.96 & 1.50 \\
\hline 13313000 & 35.3 & 44.1 & 59.7 & 54.1 & 13226500 & .145 & .187 & .708 & .500 \\
\hline 13313500 & 29.8 & 31.2 & 39.1 & 34.9 & \multicolumn{5}{|c|}{ Region 8} \\
\hline 13314000 & 191 & 230 & 338 & 317 & 9208000 & 2.10 & 2.23 & 3.05 & 2.75 \\
\hline 13314300 & 177 & 289 & 397 & 368 & 9224000 & .000 & 1.71 & 13.55 & 8.92 \\
\hline 13315000 & 2,040 & 2,480 & 2,890 & 3,120 & 10010400 & 5.39 & 5.98 & 7.86 & 6.89 \\
\hline \multicolumn{5}{|c|}{ Region 6} & 10015700 & .000 & .000 & .123 & .008 \\
\hline 6013500 & 28.8 & 30.7 & 37.6 & 34.4 & 10032000 & 39.8 & 42.8 & 55.0 & 50.7 \\
\hline 6015500 & .000 & .520 & 8.25 & 5.57 & 10040000 & 1.36 & 1.67 & 2.55 & 2.07 \\
\hline 6019500 & 54.9 & 60.4 & 84.9 & 78.9 & 10040500 & 1.40 & 1.47 & 3.21 & 2.34 \\
\hline 6037500 & 283 & 301 & 361 & 335 & 10041000 & 6.96 & 7.73 & 11.9 & 9.96 \\
\hline 13108500 & 4.46 & 4.46 & 14.43 & 7.94 & 10047500 & 3.03 & 4.61 & 6.43 & 5.63 \\
\hline 13112000 & .000 & .000 & .000 & .000 & 10058600 & 12.5 & 12.7 & 14.8 & 13.7 \\
\hline 13113000 & .000 & .000 & 7.72 & 1.87 & 10069000 & 18.8 & 18.9 & 22.8 & 20.7 \\
\hline 13113500 & .000 & .000 & .000 & .000 & 10077000 & 39.0 & 39.7 & 46.1 & 43.4 \\
\hline 13117300 & 9.14 & 9.94 & 13.7 & 12.5 & 10093000 & 14.7 & 15.0 & 18.2 & 16.8 \\
\hline 13120000 & 12.3 & 13.7 & 17.4 & 16.3 & 10096000 & 0.879 & 1.10 & 2.15 & 1.60 \\
\hline 13120500 & 38.8 & 44.0 & 60.7 & 53.9 & 10099000 & 4.42 & 4.71 & 6.82 & 5.82 \\
\hline 13128900 & 1.63 & 1.72 & 2.83 & 2.96 & 10102300 & 2.84 & 3.30 & 4.40 & 3.84 \\
\hline 13297330 & 1.66 & 2.04 & 2.94 & 2.61 & 10104700 & 10.9 & 14.0 & 20.9 & 17.1 \\
\hline 13297350 & .000 & .000 & .137 & .093 & 10104900 & 4.67 & 5.22 & 6.79 & 6.01 \\
\hline 13297355 & 4.14 & 4.72 & 6.88 & 6.14 & 10105000 & 6.35 & 6.77 & 9.95 & 8.28 \\
\hline 13297450 & 2.79 & 3.37 & 4.39 & 4.04 & 10109000 & 14.1 & 15.0 & 56.1 & 26.6 \\
\hline 13298000 & 32.1 & 44.0 & 60.8 & 57.0 & 10113500 & 39.7 & 46.4 & 66.3 & 55.8 \\
\hline 13299000 & 6.60 & 7.09 & 10.4 & 8.82 & 13010065 & 176 & 182 & 265 & 221 \\
\hline 13302500 & 483 & 553 & 808 & 711 & 13011500 & 22.6 & 25.9 & 35.6 & 32.3 \\
\hline 13305000 & 50.0 & 55.4 & 98.3 & 86.0 & 13011900 & 74.9 & 86.2 & 100.9 & 98.8 \\
\hline 13305500 & 15.0 & 16.4 & 32.6 & 27.3 & 13012000 & 91.6 & 103 & 123 & 115 \\
\hline 13306000 & 14.4 & 18.3 & 24.8 & 23.7 & 13014500 & 106 & 118 & 132 & 133 \\
\hline 13306385 & 4.74 & 5.41 & 6.74 & 6.52 & 13018300 & 1.79 & 2.11 & 3.30 & 2.82 \\
\hline 13306500 & 34.5 & 46.9 & 65.3 & 63.7 & 13019438 & 2.86 & 3.23 & 4.60 & 3.94 \\
\hline 13307000 & 854 & 938 & 1,250 & 1,180 & 13019500 & 116 & 149 & 164 & 167 \\
\hline
\end{tabular}


Table 7. Low-flow frequency statistics for streamflow-gaging stations used in low-flow regression analyses for unregulated streams in regions 1-8 in Idaho.-Continued

[1 $Q_{10}, 1$-day, 10-year low flow; $7 Q_{10}, 7$-day, 10 -year flow; $7 Q_{2}, 7$-day, 2-year low flow; 30 $Q_{5}, 30$-day, 5-year low flow $]$

\begin{tabular}{|c|c|c|c|c|c|c|c|c|c|}
\hline $\begin{array}{c}\text { Gaging } \\
\text { station No. }\end{array}$ & $10_{10}$ & $70_{10}$ & $70_{2}$ & $30 Q_{5}$ & $\begin{array}{c}\text { Gaging } \\
\text { station No. }\end{array}$ & $10_{10}$ & $70_{10}$ & $7 Q_{2}$ & $30 O_{5}$ \\
\hline \multicolumn{5}{|c|}{ Region 8 (Continued) } & \multicolumn{5}{|c|}{ Region 8 (Continued) } \\
\hline 13023000 & 117 & 136 & 169 & 160 & 13046680 & 51.3 & 53.4 & 63.0 & 58.5 \\
\hline 13024500 & 8.70 & 8.98 & 11.5 & 10.8 & 13046995 & 278 & 303 & 381 & 352 \\
\hline 13025000 & 25.0 & 27.3 & 31.0 & 30.5 & 13047500 & 192 & 233 & 335 & 295 \\
\hline 13025500 & 21.5 & 24.2 & 31.7 & 29.6 & 13047600 & 233 & 256 & 400 & 336 \\
\hline 13027000 & 24.4 & 24.8 & 27.7 & 27.4 & 13049500 & 25.8 & 38.6 & 139 & 92.8 \\
\hline 13032000 & 12.3 & 13.9 & 17.8 & 16.5 & 13052200 & 94.2 & 112 & 165 & 144 \\
\hline 13044500 & 145 & 164 & 183 & 175 & 13054000 & 97.9 & 128 & 172 & 168 \\
\hline 13045500 & 30.4 & 36.6 & 54.7 & 47.6 & 13055000 & 246 & 278 & 335 & 318 \\
\hline
\end{tabular}

Table 8. Basin characteristics considered during the low-flow regressin analyses for unregulated streams in Idaho.

[Equation variables are shown in bold]

\begin{tabular}{|c|c|}
\hline Basin characteristic & Explanation \\
\hline$\overline{A G}$ & Pasture and hay; row crops; small grains; fallow; urban or recreational grasses \\
\hline $\boldsymbol{A}$ & Area of drainage basin \\
\hline Aluv & alluvial deposits \\
\hline Barren & Bare rock, sand, or clay; quarries, mines, or pits; transitional \\
\hline$B S$ & Average slope of drainage basin \\
\hline$D V$ & Residential, commercial, industrial, or transportation lands \\
\hline $\mathrm{E}$ & Mean drainage basin elevation \\
\hline $\mathrm{F}$ & Deciduous, evergreen, or mixed forest land \\
\hline Glacial & Glacial drift and ice \\
\hline Granite & Granitic rocks \\
\hline GT6000 & Percentage of drainage basin area above $6,000 \mathrm{ft}$ \\
\hline HS Dec & Median Dec 21 hillshading \\
\hline HS June & Median June 21 hillshading \\
\hline Loess & Loess \\
\hline Met/Sed & Metamorphic or sedimentary rocks \\
\hline NF30 & Percentage of drainage basin area with north-facing slopes greater than 30 percent \\
\hline NF50 & Percentage of drainage basin area with north-facing slopes greater than 50 percent \\
\hline $\boldsymbol{P}$ & Combination precipitation based on Molnau (1995) and PRISM (Daly and Taylor, 1998) \\
\hline $\mathrm{P} 2$ & PRISM (Daly and Taylor, 1998) precipitation \\
\hline Perim & Perimeter drainage basin, in miles \\
\hline $\boldsymbol{R}$ & Relief of drainage basin \\
\hline S30 & Percentage of drainage basin area with slopes greater than 30 percent \\
\hline$S 50$ & Percentage of drainage basin area with slopes greater than 50 percent \\
\hline Sand & Dune sand \\
\hline Shdw Dec & Percentage of drainage basin area in shadow on Dec 21 \\
\hline Shdw June & Percentage of drainage basin area in shadow on June 21 \\
\hline Shrub & Shrubland \\
\hline Slope & Average slope of drainage basin, in percent \\
\hline Undefined & Unclassified lithology units \\
\hline Upland & Grasslands or herbaceous lands \\
\hline $\boldsymbol{V}$ & Volcanic rocks \\
\hline $\boldsymbol{W}$ & Open water or perennial ice and snow \\
\hline $\mathrm{W}(2)$ & Open water \\
\hline Wetland & Woody wetlands; emergent, herbaceous wetlands \\
\hline Woody & Orchards or vineyards \\
\hline
\end{tabular}


Table 9. Basin characteristic values used to develop the final probability and estimating equations for low-flow frequency statistics for unregulated streams in regions 1-8 in Idaho.

[Locations of regions are shown in figure 1. Equation variables: $\boldsymbol{A}$, drainage area, in square miles; $\boldsymbol{P}$, mean annual precipitation, in inches; $\boldsymbol{D} \boldsymbol{V}$, developed land, in percentage of drainage area; $\boldsymbol{A G}$, agricultural land, in percentage of drainage area; $\boldsymbol{B S}$, basin slope, in percent; $\boldsymbol{W}$, water, in percentage of drainage area; $\boldsymbol{R}$, basin relief, in feet; $\boldsymbol{V}$, surficial volcanic rocks, in percentage of drainage area; $\mathbf{S 5 0}$, slopes greater than 50 percent, in percentage of drainage area]

\begin{tabular}{|c|c|c|c|c|c|c|c|c|c|}
\hline Gaging station No. & \multicolumn{9}{|c|}{ Equation variables } \\
\hline \multicolumn{10}{|c|}{ Region 1} \\
\hline 12305500 & 55.3 & 48.3 & 0.001 & 0.005 & 37.1 & 0.018 & $4,134.8$ & 14.1 & 18.0 \\
\hline 12311000 & 133.1 & 30.4 & 1.13 & 6.47 & 21.2 & .721 & $5,376.7$ & 12.3 & 4.09 \\
\hline 12316800 & 12.5 & 29.1 & .088 & .042 & 25.4 & .004 & $3,178.5$ & 4.65 & 1.89 \\
\hline 12392155 & 115.1 & 54.3 & .081 & .347 & 43.2 & .168 & $4,844.3$ & 3.78 & 37.7 \\
\hline 12392300 & 121.4 & 38.1 & .463 & .519 & 32.2 & .366 & $5,441.4$ & .000 & 12.7 \\
\hline 12393500 & 596.6 & 38.8 & .328 & .141 & 28.9 & 6.69 & $5,124.1$ & 21.1 & 14.1 \\
\hline 12396000 & 68.2 & 36.7 & .017 & .972 & 30.1 & .347 & $3,731.6$ & 17.6 & 8.12 \\
\hline 12408500 & 82.5 & 37.7 & .119 & 1.30 & 29.6 & .016 & $3,832.5$ & 4.45 & 11.1 \\
\hline 12409000 & $1,011.0$ & 27.6 & .983 & 9.74 & 22.3 & .777 & $5,308.7$ & 15.3 & 6.39 \\
\hline 12301300 & 460.2 & 32.7 & 0.463 & 1.86 & 24.5 & 0.830 & $4,956.2$ & 0.000 & 13.7 \\
\hline 12301999 & 216.0 & 24.8 & .205 & .214 & 24.3 & .041 & $3,996.5$ & .000 & 5.19 \\
\hline 12302000 & 785.3 & 28.1 & .122 & 1.15 & 26.7 & .265 & $5,103.5$ & .000 & 10.0 \\
\hline 12302055 & 843.7 & 28.0 & .175 & 1.07 & 27.2 & .249 & $5,413.7$ & .000 & 10.5 \\
\hline 12302500 & 23.7 & 53.0 & .033 & .000 & 54.1 & .847 & $5,917.3$ & 24.5 & 56.1 \\
\hline 12303100 & 11.3 & 52.6 & .009 & .000 & 48.3 & 1.60 & $4,788.9$ & 4.35 & 43.6 \\
\hline 12303500 & 125.0 & 43.9 & .735 & .426 & 38.5 & .300 & $5,752.5$ & 9.89 & 33.8 \\
\hline 12340000 & $2,283.6$ & 29.4 & .006 & 4.43 & 25.7 & .858 & $6,056.4$ & 9.00 & 11.6 \\
\hline 12341000 & 80.7 & 37.1 & .935 & .087 & 36.7 & .623 & $5,406.1$ & .600 & 26.0 \\
\hline 12343400 & 379.3 & 28.4 & .079 & .569 & 33.2 & .164 & $5,278.4$ & 82.2 & 16.2 \\
\hline 12344000 & $1,049.7$ & 31.9 & .044 & .553 & 37.7 & .185 & $6,187.1$ & 65.1 & 24.0 \\
\hline 12375900 & 7.6 & 55.1 & .000 & .000 & 59.7 & 3.98 & $5,273.5$ & .000 & 59.7 \\
\hline 12377150 & 12.4 & 69.4 & .000 & .000 & 66.8 & 1.21 & $5,901.2$ & .000 & 67.4 \\
\hline 12389500 & 641.5 & 29.6 & .063 & .362 & 30.0 & .797 & $4,998.9$ & .000 & 14.5 \\
\hline 12390700 & 181.5 & 43.7 & .038 & .036 & 43.5 & .039 & $4,349.7$ & .000 & 37.9 \\
\hline 12411000 & 334.0 & 48.2 & .021 & .006 & 40.8 & .170 & $3,722.1$ & .000 & 30.7 \\
\hline 12413000 & 893.7 & 45.4 & .076 & .177 & 41.9 & .223 & $4,637.1$ & .151 & 32.7 \\
\hline 12413140 & 15.0 & 41.5 & .042 & .000 & 49.6 & .000 & $3,461.3$ & 1.94 & 52.9 \\
\hline 12413150 & 105.6 & 42.5 & .779 & .338 & 45.8 & .130 & $4,133.8$ & 2.83 & 43.8 \\
\hline 12413210 & 181.8 & 43.3 & 1.22 & .224 & 45.8 & .127 & $4,438.3$ & 1.64 & 43.9 \\
\hline 12413470 & 287.1 & 45.1 & 1.83 & .200 & 44.6 & .220 & $4,605.6$ & 1.04 & 41.2 \\
\hline 12413500 & $1,207.4$ & 45.0 & .552 & .199 & 42.3 & .239 & $4,673.2$ & 0.360 & 34.3 \\
\hline 12414500 & $1,024.5$ & 47.0 & .036 & .014 & 41.3 & .057 & $5,487.6$ & 2.96 & 30.2 \\
\hline 12414900 & 272.6 & 37.7 & .470 & 2.44 & 25.1 & .140 & $3,792.4$ & 8.60 & 3.45 \\
\hline 12415000 & 434.5 & 35.6 & .422 & 1.54 & 23.8 & .154 & $4,214.6$ & 13.9 & 3.13 \\
\hline 12416000 & 21.5 & 38.8 & .092 & .104 & 41.8 & .126 & $3,243.5$ & .000 & 28.7 \\
\hline 13336500 & $1,913.1$ & 40.6 & .000 & .000 & 44.2 & .190 & $7,789.6$ & 56.1 & 38.6 \\
\hline
\end{tabular}


Table 925

Table 9. Basin characteristic values used to develop the final probability and estimating equations for low-flow frequency statistics for unregulated streams in regions 1-8 in Idaho.-Continued

[Locations of regions are shown in figure 1. Equation variables: $\boldsymbol{A}$, drainage area, in square miles; $\boldsymbol{P}$, mean annual precipitation, in inches; $\boldsymbol{D V}$, developed land, in percentage of drainage area; $\boldsymbol{A} \boldsymbol{G}$, agricultural land, in percentage of drainage area; $\boldsymbol{B S}$, basin slope, in percent; $\boldsymbol{W}$, water, in percentage of drainage area; $\boldsymbol{R}$, basin relief, in feet; $\boldsymbol{V}$, surficial volcanic rocks, in percentage of drainage area; $\mathbf{S 5 0}$, slopes greater than 50 percent, in percentage of drainage area]

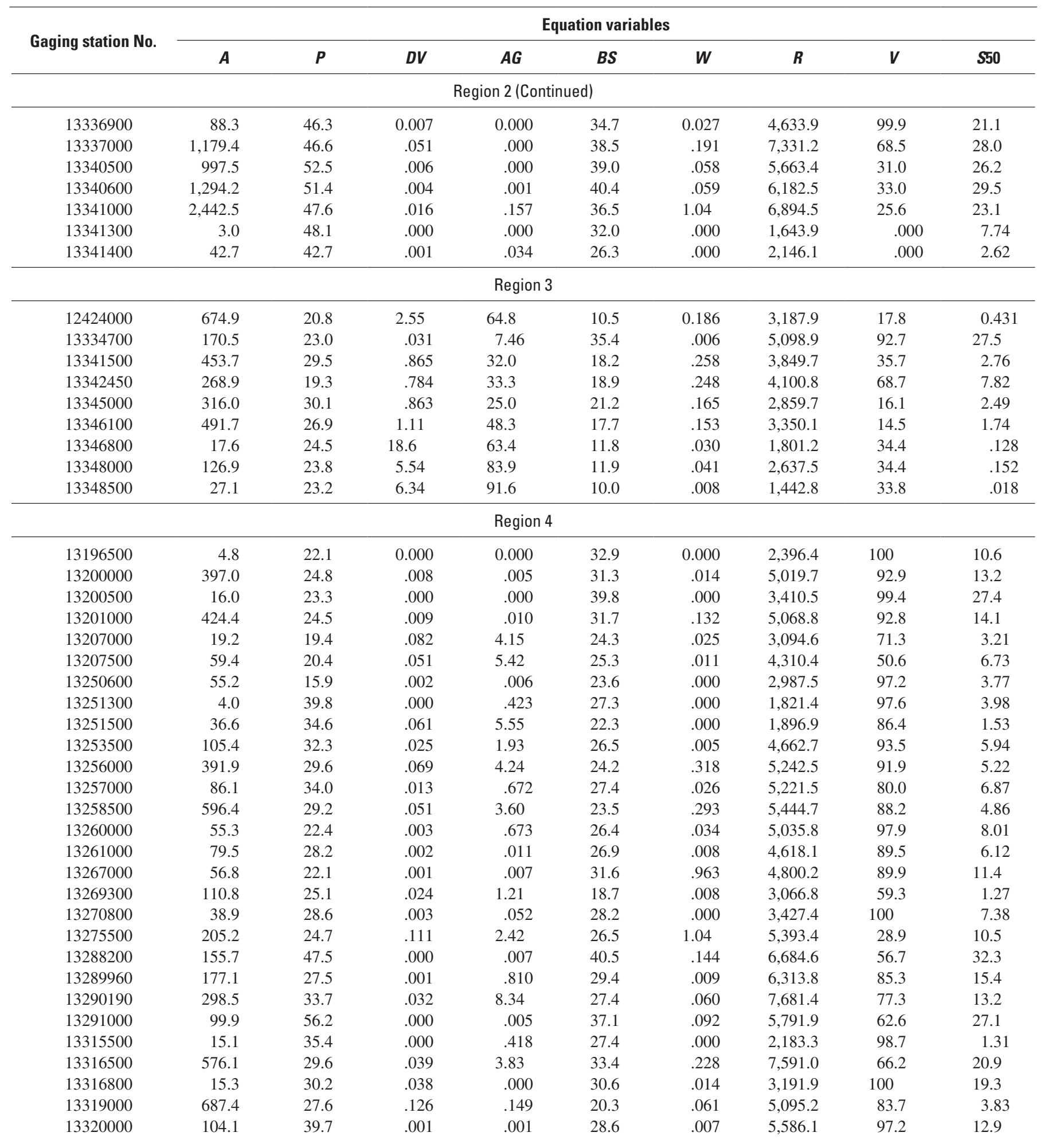


Table 9. Basin characteristic values used to develop the final probability and estimating equations for low-flow frequency statistics for unregulated streams in regions 1-8 in Idaho.-Continued

[Locations of regions are shown in figure 1. Equation variables: $\boldsymbol{A}$, drainage area, in square miles; $\boldsymbol{P}$, mean annual precipitation, in inches; $\boldsymbol{D} \boldsymbol{V}$, developed land, in percentage of drainage area; $\boldsymbol{A G}$, agricultural land, in percentage of drainage area; $\boldsymbol{B S}$, basin slope, in percent; $\boldsymbol{W}$, water, in percentage of drainage area; $\boldsymbol{R}$, basin relief, in feet; $\boldsymbol{V}$, surficial volcanic rocks, in percentage of drainage area; $\mathbf{S 5 0}$, slopes greater than 50 percent, in percentage of drainage area]

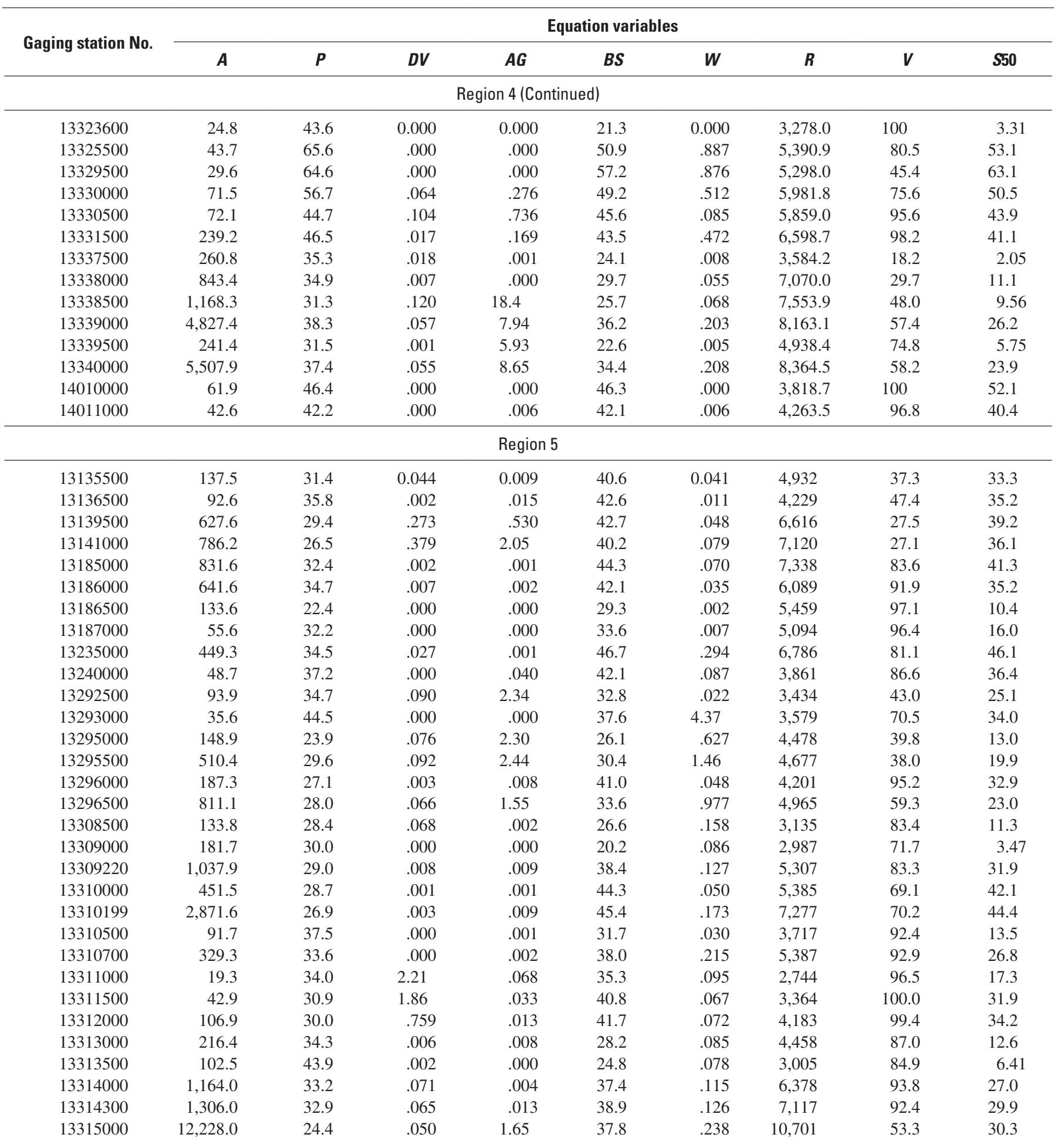


Table 9. Basin characteristic values used to develop the final probability and estimating equations for low-flow frequency statistics for unregulated streams in regions 1-8 in Idaho.-Continued

[Locations of regions are shown in figure 1. Equation variables: $\boldsymbol{A}$, drainage area, in square miles; $\boldsymbol{P}$, mean annual precipitation, in inches; $\boldsymbol{D} \boldsymbol{V}$, developed land, in percentage of drainage area; $\boldsymbol{A} \boldsymbol{G}$, agricultural land, in percentage of drainage area; $\boldsymbol{B S}$, basin slope, in percent; $\boldsymbol{W}$, water, in percentage of drainage area; $\boldsymbol{R}$, basin relief, in feet; $\boldsymbol{V}$, surficial volcanic rocks, in percentage of drainage area; $\mathbf{S 5 0}$, slopes greater than 50 percent, in percentage of drainage area]

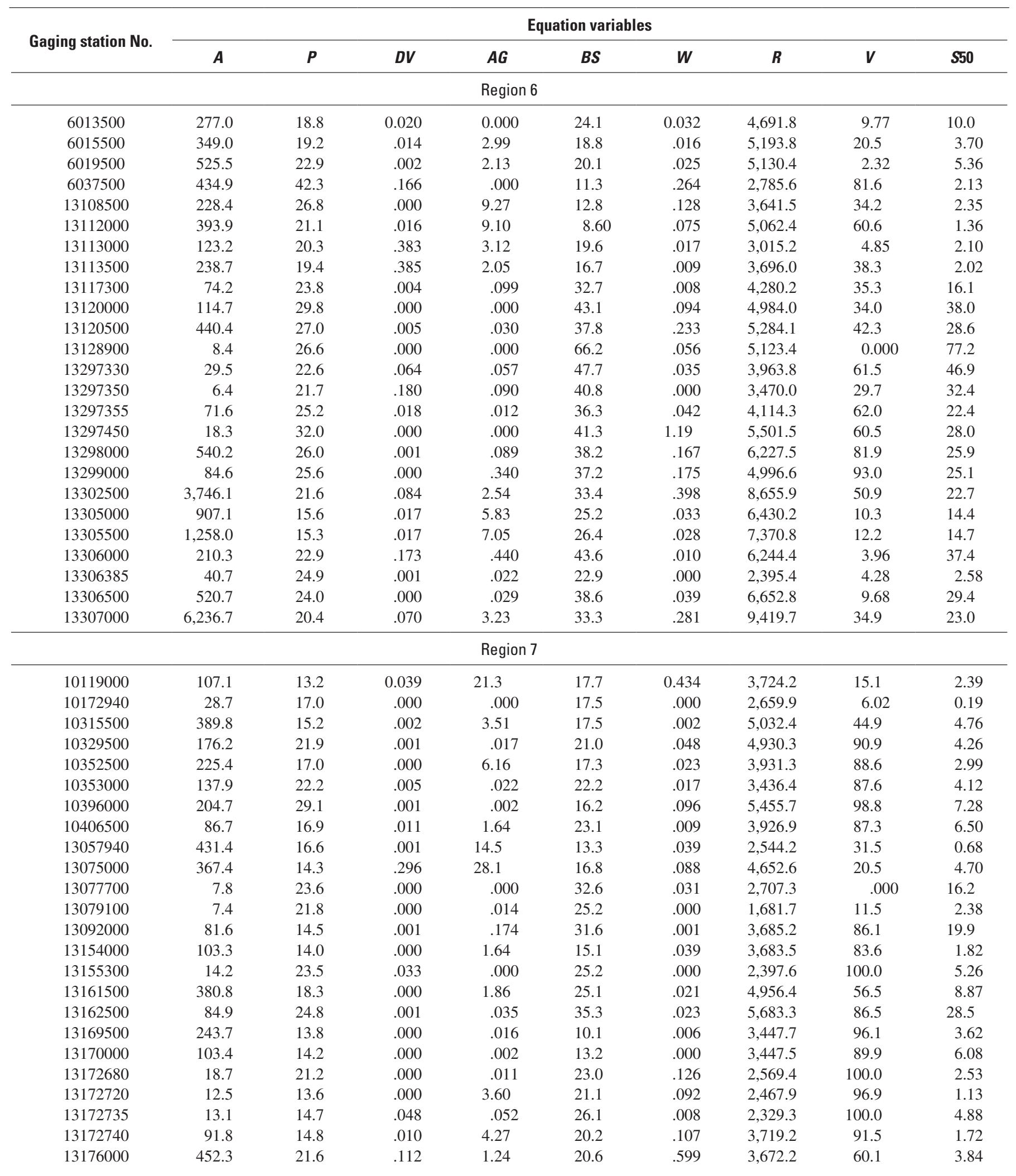


Table 9. Basin characteristic values used to develop the final probability and estimating equations for low-flow frequency statistics for unregulated streams in regions 1-8 in Idaho.-Continued

[Locations of regions are shown in figure 1. Equation variables: $\boldsymbol{A}$, drainage area, in square miles; $\boldsymbol{P}$, mean annual precipitation, in inches; $\boldsymbol{D} \boldsymbol{V}$, developed land, in percentage of drainage area; $\boldsymbol{A G}$, agricultural land, in percentage of drainage area; $\boldsymbol{B S}$, basin slope, in percent; $\boldsymbol{W}$, water, in percentage of drainage area; $\boldsymbol{R}$, basin relief, in feet; $\boldsymbol{V}$, surficial volcanic rocks, in percentage of drainage area; $\mathbf{S 5 0}$, slopes greater than 50 percent, in percentage of drainage area]

\begin{tabular}{|c|c|c|c|c|c|c|c|c|c|}
\hline Gaging station No. & \multicolumn{9}{|c|}{ Equation variables } \\
\hline \multicolumn{10}{|c|}{ Region 7 (Continued) } \\
\hline 13177000 & 26.8 & 29.3 & 0.005 & 0.505 & 29.9 & 0.016 & $4,247.5$ & 0.362 & 10.5 \\
\hline 13178000 & 454.2 & 26.1 & .258 & .726 & 19.5 & .221 & $3,905.0$ & 79.3 & 3.69 \\
\hline 13226500 & 535.3 & 12.3 & .016 & 1.86 & 17.4 & .026 & $3,958.2$ & 73.5 & 1.47 \\
\hline 9208000 & 6.6 & 40.3 & 0.000 & 0.000 & 29.6 & 0.000 & $1,442.8$ & 0.000 & 10.6 \\
\hline 9224000 & 390.1 & 23.6 & .057 & .434 & 15.4 & .747 & $3,048.4$ & .000 & 1.56 \\
\hline 10010400 & 34.5 & 40.4 & .000 & .101 & 39.5 & 2.15 & $3,997.8$ & .000 & 31.1 \\
\hline 10015700 & 58.5 & 21.6 & .000 & 10.8 & 9.65 & .000 & $2,997.9$ & .000 & .002 \\
\hline 10032000 & 165.2 & 34.1 & .000 & .000 & 31.3 & .500 & $4,033.0$ & .000 & 13.3 \\
\hline 10058600 & 24.3 & 35.1 & .000 & .000 & 27.4 & .071 & $3,487.4$ & .806 & 7.64 \\
\hline 10069000 & 21.9 & 26.1 & .000 & .000 & 41.0 & .044 & $3,534.8$ & .000 & 31.9 \\
\hline 10077000 & 50.9 & 18.2 & .000 & 70.7 & 6.15 & .157 & $1,100.5$ & 77.0 & .639 \\
\hline 10093000 & 30.4 & 36.0 & .000 & .000 & 31.3 & .022 & $3,983.1$ & .000 & 19.4 \\
\hline 10096000 & 23.2 & 14.2 & .011 & 17.9 & 19.8 & .000 & $1,695.4$ & .000 & 1.13 \\
\hline 10099000 & 16.3 & 40.9 & .000 & .000 & 49.4 & .003 & $4,510.9$ & .000 & 50.2 \\
\hline 10102300 & 11.6 & 39.3 & .000 & .000 & 53.2 & .182 & $4,577.3$ & .000 & 60.5 \\
\hline 10104700 & 62.2 & 38.0 & .000 & 1.05 & 30.1 & .040 & $4,381.5$ & .000 & 14.5 \\
\hline 10104900 & 56.8 & 35.4 & .000 & .000 & 28.3 & .040 & $3,719.8$ & .000 & 16.3 \\
\hline 10105000 & 69.2 & 35.2 & .000 & .000 & 30.1 & .368 & $3,932.8$ & .000 & 18.9 \\
\hline 10109000 & 214.4 & 35.6 & .010 & .008 & 33.3 & .175 & $5,255.6$ & .000 & 20.0 \\
\hline 10113500 & 264.6 & 28.3 & .000 & .153 & 28.5 & .097 & $4,206.7$ & .000 & 14.9 \\
\hline 13023000 & 448.8 & 34.9 & .003 & .105 & 35.1 & .059 & $5,632.6$ & .000 & 22.5 \\
\hline 13024500 & 25.7 & 39.5 & .000 & .000 & 45.1 & .311 & $3,738.3$ & .000 & 40.0 \\
\hline 13025000 & 27.7 & 39.3 & .000 & .000 & 49.3 & .000 & $4,223.5$ & .000 & 52.2 \\
\hline 13025500 & 113.8 & 29.4 & .000 & 2.83 & 24.9 & .261 & $3,647.1$ & .000 & 5.63 \\
\hline 13027000 & 20.1 & 40.8 & .000 & .000 & 49.7 & .000 & $3,663.7$ & .000 & 50.1 \\
\hline 13032000 & 78.3 & 26.7 & .000 & .000 & 38.8 & .135 & $3,806.4$ & .000 & 26.3 \\
\hline 13044500 & 131.1 & 31.8 & .000 & .000 & 9.05 & .255 & $2,604.8$ & 62.8 & .475 \\
\hline 13045500 & 123.7 & 35.3 & .000 & 2.44 & 10.6 & .582 & $2,516.2$ & 61.5 & 1.05 \\
\hline 13046680 & 85.4 & 56.0 & .001 & .000 & 6.94 & .232 & $2,270.2$ & 90.1 & .656 \\
\hline 13046995 & 322.3 & 53.5 & .001 & .000 & 10.9 & 1.48 & $3,501.7$ & 84.2 & 1.75 \\
\hline 13047500 & 333.6 & 52.9 & .000 & .110 & 11.0 & .755 & $3,655.8$ & 82.8 & 1.71 \\
\hline 13047600 & 336.9 & 52.2 & .001 & 2.35 & 10.8 & 1.48 & $3,897.7$ & 82.0 & 1.68 \\
\hline 13049500 & 512.9 & 42.6 & .020 & 19.5 & 9.89 & .582 & $4,197.5$ & 71.3 & 1.52 \\
\hline 13052200 & 341.4 & 31.7 & .176 & 24.8 & 23.6 & .290 & $5,223.4$ & 9.11 & 15.4 \\
\hline 13054000 & 479.2 & 30.3 & .138 & 26.7 & 21.5 & .350 & $5,277.0$ & 18.7 & 12.9 \\
\hline 13055000 & 874.8 & 27.7 & .080 & 32.8 & 19.0 & .281 & $6,232.1$ & 47.7 & 9.69 \\
\hline
\end{tabular}


Table 10. Total years with the $\mathrm{N}$-day low flow equal to zero and total years of record for streamflow-gaging stations used in logistic regression analyses for unregulated streams in regions $1-8$ in Idaho.

\begin{tabular}{ccccc}
\hline $\begin{array}{c}\text { Gaging station } \\
\text { No. }\end{array}$ & $\begin{array}{c}\text { 1-day zero } \\
\text { flow }\end{array}$ & $\begin{array}{c}\text { 7-day zero } \\
\text { flow }\end{array}$ & $\begin{array}{c}\text { 30-day zero } \\
\text { flow }\end{array}$ & $\begin{array}{c}\text { Total years } \\
\text { of record }\end{array}$ \\
\hline \multicolumn{5}{c}{ Region 1 } \\
\hline 12305500 & 0 & 0 & 0 & 45 \\
12311000 & 0 & 0 & 0 & 42 \\
12316800 & 0 & 0 & 0 & 22 \\
12320500 & 0 & 0 & 0 & 28 \\
12321000 & 0 & 0 & 0 & 30 \\
12392155 & 1 & 1 & 0 & 12 \\
12392300 & 0 & 0 & 0 & 23 \\
12393500 & 0 & 0 & 0 & 32 \\
12396000 & 0 & 0 & 0 & 22 \\
12408500 & 0 & 0 & 0 & 40 \\
12409000 & 0 & 0 & 0 & 79 \\
12427000 & 0 & 0 & 0 & 22 \\
12431000 & 0 & 0 & 0 & 58 \\
\hline
\end{tabular}

Region 2

\begin{tabular}{ccccc}
\hline $\begin{array}{c}\text { Gaging station } \\
\text { No. }\end{array}$ & $\begin{array}{c}\text { 1-day zero } \\
\text { flow }\end{array}$ & $\begin{array}{c}\text { 7-day zero } \\
\text { flow }\end{array}$ & $\begin{array}{c}\text { 30-day zero } \\
\text { flow }\end{array}$ & $\begin{array}{c}\text { Total years } \\
\text { of record }\end{array}$ \\
\hline \multicolumn{5}{c}{ Region 2 (Continued) } \\
\hline 13341000 & 0 & 0 & 0 & 38 \\
13341300 & 0 & 0 & 0 & 11 \\
13341400 & 0 & 0 & 0 & 11 \\
\hline \multicolumn{5}{c}{ Region 3 } \\
\hline 12424000 & 0 & 0 & 0 & 53 \\
13334700 & 0 & 0 & 0 & 22 \\
13341500 & 0 & 0 & 0 & 14 \\
13342450 & 0 & 0 & 0 & 28 \\
13345000 & 0 & 0 & 0 & 40 \\
13346100 & 0 & 0 & 0 & 10 \\
13346800 & 0 & 0 & 0 & 24 \\
13348000 & 0 & 0 & 0 & 30 \\
13348500 & 5 & 4 & 3 & 25 \\
\hline
\end{tabular}

$\begin{array}{rlllr}12301300 & 0 & 0 & 0 & 44 \\ 12301999 & 0 & 0 & 0 & 9 \\ 12302000 & 0 & 0 & 0 & 18 \\ 12302055 & 0 & 0 & 0 & 35 \\ 12302500 & 0 & 0 & 0 & 14 \\ 12303100 & 0 & 0 & 0 & 31 \\ 12303500 & 0 & 0 & 0 & 24 \\ 12340000 & 0 & 0 & 0 & 65 \\ 12341000 & 0 & 0 & 0 & 8 \\ 12343400 & 0 & 0 & 0 & 18 \\ 12344000 & 0 & 0 & 0 & 66 \\ 12346500 & 0 & 0 & 0 & 27 \\ 12347500 & 0 & 0 & 0 & 22 \\ 12350000 & 0 & 0 & 0 & 16 \\ 12350500 & 0 & 0 & 0 & 9 \\ 12351000 & 0 & 0 & 0 & 23 \\ 12352000 & 0 & 0 & 0 & 9 \\ 12353280 & 0 & 0 & 0 & 9 \\ 12354000 & 0 & 0 & 0 & 17 \\ 12375900 & 0 & 0 & 0 & 20 \\ 12377150 & 0 & 0 & 0 & 20 \\ 12389500 & 0 & 0 & 0 & 47 \\ 12390700 & 0 & 0 & 0 & 47 \\ 12411000 & 0 & 0 & 0 & 52 \\ 12413000 & 0 & 0 & 0 & 63 \\ 12413140 & 0 & 0 & 0 & 30 \\ 12413150 & 0 & 0 & 0 & 20 \\ 12413210 & 0 & 0 & 0 & 13 \\ 12413470 & 0 & 0 & 0 & 15 \\ 12413500 & 0 & 0 & 0 & 67 \\ 12414500 & 0 & 0 & 0 & 82 \\ 12414900 & 0 & 0 & 0 & 37 \\ 12415000 & 0 & 0 & 0 & 45 \\ 12416000 & 0 & 0 & 0 & 36 \\ 13336500 & 0 & 0 & 0 & 73 \\ 13336900 & 0 & 0 & 0 & 9 \\ 13337000 & 0 & 0 & 0 & 74 \\ 13340500 & 0 & 0 & 0 & 24 \\ 13340600 & 0 & 0 & 0 & 35 \\ & 0 & 0 & 0\end{array}$

Region 4

$\begin{array}{lllll}13196500 & 0 & 0 & 0 & 22\end{array}$

$13200000 \quad 0 \quad 00052$

$\begin{array}{lllll}13200500 & 2 & 0 & 0 & 20\end{array}$

$\begin{array}{lrrrr}13201000 & 0 & 0 & 0 & 38\end{array}$

$\begin{array}{lllll}13207000 & 14 & 14 & 14 & 14\end{array}$

$\begin{array}{lllll}13207500 & 5 & 2 & 1 & 13\end{array}$

$\begin{array}{lllll}13250600 & 0 & 0 & 0 & 20\end{array}$

$\begin{array}{lllll}13251300 & 0 & 0 & 0 & 17\end{array}$

$\begin{array}{lllll}13251500 & 0 & 0 & 0 & 35\end{array}$

$\begin{array}{lllll}13253500 & 0 & 0 & 0 & 10\end{array}$

$\begin{array}{lllll}13256000 & 0 & 0 & 0 & 15\end{array}$

$\begin{array}{lllll}13257000 & 3 & 3 & 2 & 16\end{array}$

$\begin{array}{lllll}13258500 & 0 & 0 & 0 & 64\end{array}$

$\begin{array}{lllll}13260000 & 0 & 0 & 0 & 23\end{array}$

$\begin{array}{lllll}13261000 & 0 & 0 & 0 & 35\end{array}$

$\begin{array}{lllll}13267000 & 1 & 1 & 1 & 25\end{array}$

$\begin{array}{lllll}13269300 & 0 & 0 & 0 & 13\end{array}$

$\begin{array}{lllll}13270800 & 0 & 0 & 0 & 18\end{array}$

$\begin{array}{lllll}13275500 & 2 & 0 & 0 & 49\end{array}$

$\begin{array}{lllll}13288200 & 0 & 0 & 0 & 39\end{array}$

$\begin{array}{lllll}13289960 & 0 & 0 & 0 & 17\end{array}$

$\begin{array}{lllll}13290190 & 0 & 0 & 0 & 29\end{array}$

$\begin{array}{lllll}13291000 & 0 & 0 & 0 & 8\end{array}$

$\begin{array}{lllll}13315500 & 0 & 0 & 0 & 13\end{array}$

$\begin{array}{lllll}13316500 & 0 & 0 & 0 & 49\end{array}$

$\begin{array}{lllll}13316800 & 0 & 0 & 0 & 11\end{array}$

$\begin{array}{lllll}13319000 & 0 & 0 & 0 & 78\end{array}$

$\begin{array}{lllll}13320000 & 0 & 0 & 0 & 64\end{array}$

$\begin{array}{lllll}13323600 & 0 & 0 & 0 & 12\end{array}$

$\begin{array}{rrrrr}13325500 & 0 & 0 & 0 & 8\end{array}$

$\begin{array}{lllll}13329500 & 0 & 0 & 0 & 53\end{array}$

$\begin{array}{lllll}13330000 & 0 & 0 & 0 & 73\end{array}$

$\begin{array}{lllll}13330500 & 0 & 0 & 0 & 68\end{array}$

$\begin{array}{lllll}13330500 & 0 & 0 & 0 & 38\end{array}$

$\begin{array}{lllll}13337500 & 0 & 0 & 0 & 29\end{array}$

$\begin{array}{lllll}13338000 & 0 & 0 & 0 & 44\end{array}$

$\begin{array}{lllll}13338500 & 0 & 0 & 0 & 38\end{array}$


Table 10. Total years with the $\mathrm{N}$-day low flow equal to zero and total years of record for streamflow-gaging stations used in logistic regression analyses for unregulated streams in regions 1-8 in Idaho.-Continued

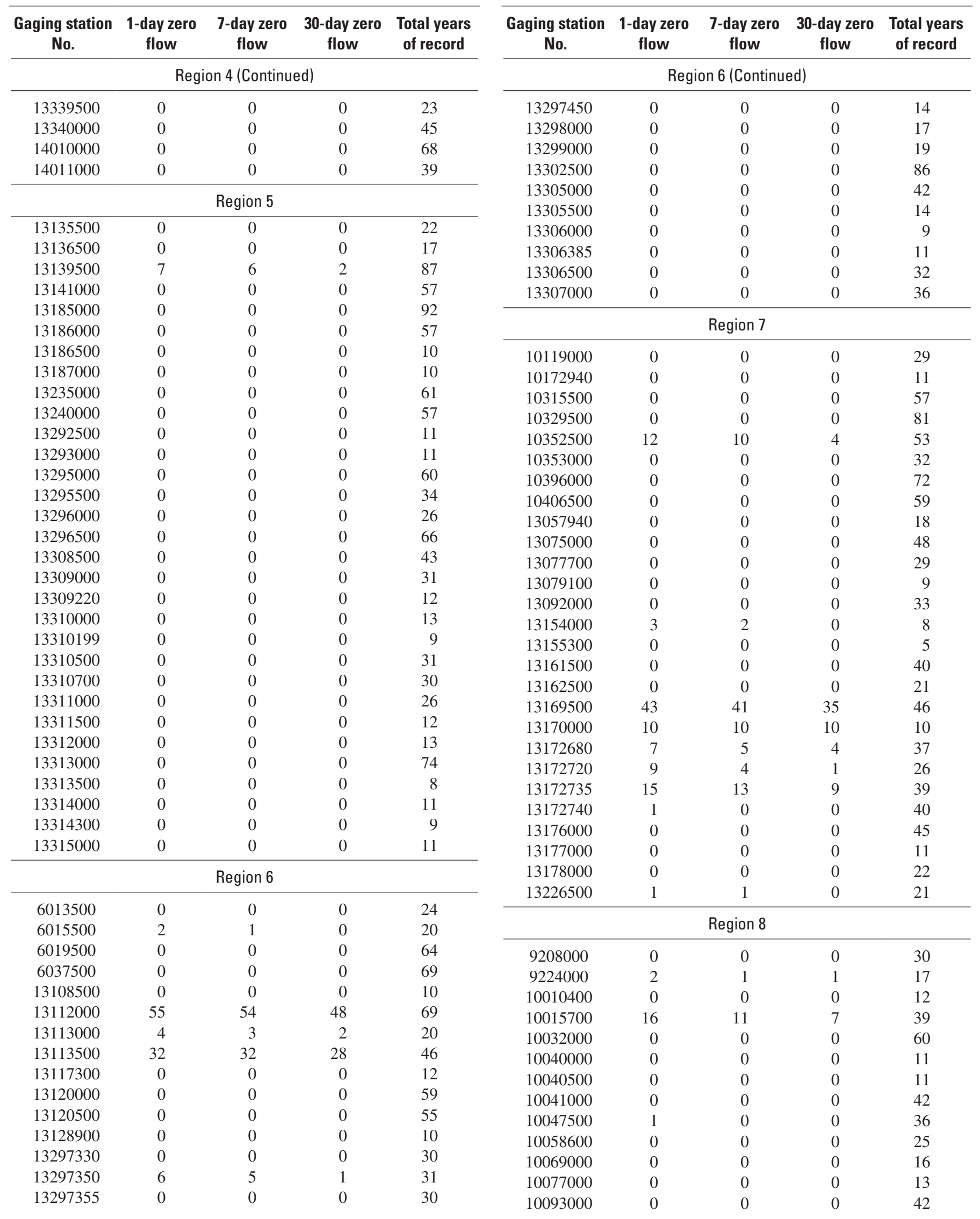


Table 10. Total years with the N-day low flow equal to zero and total years of record for streamflow-gaging stations used in logistic regression analyses for unregulated streams in regions 1-8 in Idaho.-Continued

\begin{tabular}{|c|c|c|c|c|c|c|c|c|c|}
\hline $\begin{array}{c}\text { Gaging station } \\
\text { No. }\end{array}$ & $\begin{array}{l}\text { 1-day zero } \\
\text { flow }\end{array}$ & $\begin{array}{l}\text { 7-day zero } \\
\text { flow }\end{array}$ & $\begin{array}{l}\text { 30-day zero } \\
\text { flow }\end{array}$ & $\begin{array}{l}\text { Total years } \\
\text { of record }\end{array}$ & $\begin{array}{c}\text { Gaging station } \\
\text { No. }\end{array}$ & $\begin{array}{l}\text { 1-day zero } \\
\text { flow }\end{array}$ & $\begin{array}{l}\text { 7-day zero } \\
\text { flow }\end{array}$ & $\begin{array}{l}\text { 30-day zero } \\
\text { flow }\end{array}$ & $\begin{array}{c}\text { Total years } \\
\text { of record }\end{array}$ \\
\hline \multicolumn{5}{|c|}{ Region 8 (Continued) } & \multicolumn{5}{|c|}{ Region 8 (Continued) } \\
\hline 10096000 & 0 & 0 & 0 & 12 & 13023000 & 0 & 0 & 0 & 51 \\
\hline 10099000 & 0 & 0 & 0 & 17 & 13024500 & 0 & 0 & 0 & 24 \\
\hline 10102300 & 0 & 0 & 0 & 17 & 13025000 & 0 & 0 & 0 & 28 \\
\hline 10104700 & 0 & 0 & 0 & 31 & 13025500 & 0 & 0 & 0 & 8 \\
\hline 10104900 & 0 & 0 & 0 & 22 & 13027000 & 0 & 0 & 0 & 10 \\
\hline 10105000 & 0 & 0 & 0 & 11 & 13032000 & 0 & 0 & 0 & 17 \\
\hline 10109000 & 0 & 0 & 0 & 49 & 13044500 & 0 & 0 & 0 & 14 \\
\hline 10113500 & 0 & 0 & 0 & 83 & 13045500 & 0 & 0 & 0 & 17 \\
\hline 13010065 & 0 & 0 & 0 & 19 & 13046680 & 0 & 0 & 0 & 17 \\
\hline 13011500 & 0 & 0 & 0 & 54 & 13046995 & 0 & 0 & 0 & 18 \\
\hline 13011900 & 0 & 0 & 0 & 37 & 13047500 & 0 & 0 & 0 & 9 \\
\hline 13012000 & 0 & 0 & 0 & 15 & 13047600 & 0 & 0 & 0 & 87 \\
\hline 13014500 & 0 & 0 & 0 & 13 & 13049500 & 0 & 0 & 0 & 9 \\
\hline 13018300 & 0 & 0 & 0 & 40 & 13052200 & 0 & 0 & 0 & 42 \\
\hline 13019438 & 0 & 0 & 0 & 10 & 13054000 & 0 & 0 & 0 & 41 \\
\hline 13019500 & 0 & 0 & 0 & 13 & 13055000 & 0 & 0 & 0 & 76 \\
\hline
\end{tabular}


Manuscript approved for publication, February 3, 2006

Prepared by the Enterprise Publishing Network,

Publishing Service Center, Tacoma, Washington

Bill Gibbs

Sharon Wahlstrom

Judy Wayenberg

For more information concerning the research in this report, contact the Idaho Water Science Center Director,

U.S. Geological Survey, 230 Collins Road

Boise, Idaho 83702-4520

http://id.water.usgs.gov 


\section{$\mathbb{E}$ 奇}

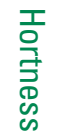

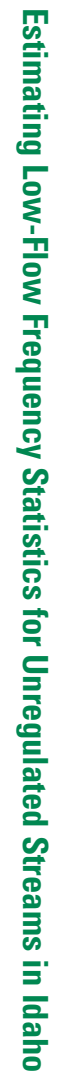

